\title{
Mass spectrometry of metallothionein adducts as candidate biomarkers of styrene oxide and 1-phenylpropylene oxide
}

\author{
Sandra G. Tarr \\ West Virginia University
}

Follow this and additional works at: https://researchrepository.wvu.edu/etd

\section{Recommended Citation}

Tarr, Sandra G., "Mass spectrometry of metallothionein adducts as candidate biomarkers of styrene oxide and 1-phenylpropylene oxide" (2005). Graduate Theses, Dissertations, and Problem Reports. 4199. https://researchrepository.wvu.edu/etd/4199

This Thesis is protected by copyright and/or related rights. It has been brought to you by the The Research Repository @ WVU with permission from the rights-holder(s). You are free to use this Thesis in any way that is permitted by the copyright and related rights legislation that applies to your use. For other uses you must obtain permission from the rights-holder(s) directly, unless additional rights are indicated by a Creative Commons license in the record and/ or on the work itself. This Thesis has been accepted for inclusion in WVU Graduate Theses, Dissertations, and Problem Reports collection by an authorized administrator of The Research Repository @ WVU. For more information, please contact researchrepository@mail.wvu.edu. 
Mass Spectrometry of Metallothionein Adducts as Candidate Biomarkers of Styrene Oxide and 1-Phenylpropylene Oxide

\author{
Sandra G. Tarr \\ A Thesis \\ Submitted to \\ The School of Pharmacy \\ At \\ West Virginia University \\ In partial fulfillment of the requirements \\ For the degree of \\ Master of Science \\ In \\ Pharmaceutical Sciences \\ Patrick Callery, Ph.D., Chair \\ Grazyna Szklarz, Ph. D. \\ Fred King, Ph. D. \\ Department of Basic Pharmaceutical Sciences \\ Morgantown, West Virginia




\section{ABSTRACT \\ Mass Spectrometry of Metallothionein Adducts as Candidate Biomarkers of Styrene Oxide and 1-Phenylpropylene Oxide}

Sandra G. Tarr

Metallothioneins (MT) are cysteine-rich intracellular proteins that sequester epoxides, such as the genotoxic styrene metabolite, styrene oxide (SO). Covalent adduct formation by the ring-opening of SO and its homologue, 1-phenylpropylene oxide (trans), with MT forms stable complexes that potentially may serve as biomarkers for epoxide exposure. MT was reacted with SO and trans-phenylpropylene oxide (PPO) separately in water. Mass spectra of adducts were obtained using electrospray ionization with positive-ion detection in an ion trap mass spectrometer. MS/MS analysis established the covalent nature of the complexation. Further experiments were conducted to determine the site of adduct formation. Molecular modeling was used to predict the most likely site of adduct formation. Alkylation and digestion were used to locate the peptide fragment where adduct formation occurred and confirm modeling results. The likeliest cysteine residue was residue 48 in the alpha domain of MT. MT-SO adducts provide a basis for the development of biomarkers. 


\section{ACKNOWLEDGMENTS}

I would first like to thank my advisor, Dr. Patrick Callery, for his advice and confidence in me. He has been tremendous help to me in this whole process. I would also like to thank Dr. Grazyna Szklarz and Dr. Fred King for agreeing to serve on my committee. I want to also thank Dr. Diaa Shakleya for all of his help and guidance throughout this project. I want to also thank the entire Pharmaceutical Sciences Department, faculty, staff, and students for all of their help and support. I wish to thank Mylan Pharmaceuticals and my colleagues in the Bioanalytical Department, especially Dr. Scott Chervenick, who gave me the time and encouragement to continue my education. Finally, I would also like to especially thank my mother, family, and friends for all of their love, encouragement, and support. 
TABLE OF CONTENTS

$\begin{array}{ll}\text { Abstract } & \text { ii } \\ \text { Acknowledgments } & \text { iii } \\ \text { Table of Contents } & \text { iv } \\ \text { List of Figures } & \text { v } \\ \text { List of Tables } & \text { vi } \\ \text { List of abbreviations } & \text { vii } \\ \text { 1. Introduction } & 1 \\ \text { 2. Methods and Materials } & 5 \\ \text { 3.1 Results } & 9 \\ \text { 3.2 Discussion } & 12 \\ \text { 4. Summary and Conclusions } & 15 \\ \text { 5. Reference List } & 41\end{array}$




\section{LIST OF FIGURES}

Figure 2.1 Alpha Domain of Mouse Metallothionein-I 17

Figure 2.2 Beta Domain of Mouse Metallothionein-I 18

Figure 2.3 Styrene Oxide and trans-Phenylpropylene Oxide 19

Figure 3.1 Mass Spectrum of Metallothionein-I 27

Figure 3.2 Mass Spectrum of Metallothionein-I/Styrene oxide Adduct 28

Figure 3.3 Mass Spectrum of apo-Metallothionein-I 29

Figure 3.4 Mass Spectrum of MT-I/SO Adduct after metal Removal 30

Figure 3.5 Mass Spectrum of MT-I/PPO Adduct after Metal Removal 31

Figure 3.6 Mass Spectrum of apoMT-I/SO Adduct 32

Figure 3.7 MS/MS of Metallothionein-I at +5 Charge State 33

Figure 3.8 MS/MS of MT-I/SO Adduct at +5 Charge State 34

Figure 3.9 MS/MS of MT-I/PPO Adduct at +5 Charge State 35

Figure 3.10 Mass Spectrum of Metallothionein-I Digest 36

Figure 3.11 Mass Spectrum of MT-I/SO Adduct Digest 37

Figure 3.12 Proposed Structure for SO Adducted Peptide Fragment 44-51 for MT 38

Figure 3.13 Proposed Metallothionein-I/Styrene Oxide Adduct

at Cysteine Residue 48

Figure 3.14 Proposed Structure of MS/MS Fragment Corresponding to Loss of 288

40 


\section{LIST OF TABLES}

Table 2.1 Amino Acid Sequence Comparison of Mouse to Rabbit MT-I 16

Table $3.1 \quad$ Adduct Formation for MT-I with Styrene Oxide and trans-Phenylpropylene Oxide

Table 3.2 Product vs. Precursor Ions for Various Charge States of Metallothionein Adducts

Table 3.4 Total Energies of Final Structures for Alpha and Beta Adducts

Table 3.4 Optimal Protein-Ligand Distances in the $\alpha$-Domain of less than $6 \AA$

Table 3.5 Optimal Protein-Ligand Distances in the $\beta$-Domain of less than $6 \AA$

Table 3.6 Metallothionein-I Peptide Mapping

Table 3.7 Collision Energy Comparison of Precursor vs. Product Ions at +5 Charge State 


\section{LIST OF ABBREVIATIONS}

apo-MT

DTT

ESI

EDTA

MS/MS

MT

$\mathrm{m} / \mathrm{z}$

PPO

$\mathrm{SO}$

TFA apo-metallothionein

dithiothreitol

electrospray ionization

ethylenediaminetetraacetic acid tandem mass spectrometry

metallothionein

mass to charge

trans-phenylpropylene oxide

styrene oxide

trifluroacetic acid 


\section{CHAPTER I}

\section{Introduction}


Metallothioneins are small intracellular cysteine-rich proteins 60-62 amino acid residues in size. Metallothioneins have been found in practically all life forms and have been isolated from different organs such as the liver, kidney, and brain (Sanz-Nebot, 2003). In mammals, the two major isoforms, MT1 and MT2, are the most abundant in the liver, kidney, pancreas, and intestines (Zangger, 2001).

The conventional nomenclature division of MT1 versus MT2 refers to the absence (MT1) or presence (MT2) of an acidic amino acid residue in position 10 or 11 of the protein sequence (Sanz-Nebot, 2003). Isoforms with minor differences are detected as subgroups of the two main isoforms (MT1 and MT2). The subgroup's specific biological roles still remain unknown.

Mammalian metallothionein binds 7 divalent metal ions to its 20 cysteine residues (Hong, 2001). Metallothionein is comprised of two globular domains. The N-terminal $\beta$ domain, residues 1-30, binds three metals to nine cysteine residues in a cluster formation. The C-terminal $\alpha$-domain, residues 31-61, binds four metals to eleven cysteine residues in another cluster formation (Zangger, 2001).

Metallothioneins are believed to play a physiological role in the metabolism of toxic metals including zinc, copper and cadmium (Gehrig, 1999). Metallothionein has also been shown to be involved in cellular defense mechanisms associated with oxidation and stress (Koh, 2001). Overexpression of metallothioneins is readily induced by a variety of endogenous and exogenous chemicals and elevated metallothionein levels have been correlated with resistance to electrophilic molecules used in chemotherapy (He, 2000). The proposed mechanism is that increased amounts of metallothionein provide increased intracellular drug sequestration, thus reducing the amount reaching the target DNA (Zaia, 1996).

Metallothionein has been previously shown to form covalent adducts with various therapeutic agents. These include chlorambucil (Zaia, 1996), the anticancer agent melphalan (Yu, 1995), the nitrogen mustard mechlorethamine (Antoine, 1998), and phosphoramide mustard (Wei, 1999). 
Styrene is a widely used industrial chemical. Chronic exposure to styrene has been shown to produce reproductive, developmental, genotoxic, and carcinogenic effects in laboratory animals (Linhart, 2001). Styrene's main metabolite, styrene oxide (SO), is considered to be responsible for the toxic effects of exposure to styrene. The epoxide is formed from styrene through microsomal monooxygenase (Watabe, 1981).

Smoking of methamphetamine hydrochloride laced tobacco yields several volatile products formed through pyrolysis. One such product is 1-phenylpropene (Sato, 2001). trans-phenylpropylene oxide (PPO) is a metabolite of 1-phenylpropene as well as a homologue of styrene oxide. The objective of our experiments was to form adducts between styrene oxide and trans-phenylpropylene oxide with metallothionein.

Various analytical techniques have been used to characterize metallothionein. Isoelectric focusing has been used to separate isoforms of rabbit metallothionein (Nordberg, 1972). Matrix-assisted laser desorption ionization (MALDI) mass spectrometry has been used to study the interaction of sulfur mustard exposure with metallothionein (Price, 2000). Metallothionein dimers have been characterized by nanospray mass spectrometry (Hathout, 2002). Liquid chromatography and capillary electrophoresis are also techniques employed to characterize metallothioneins (Dabrio, 2002).

The analytical technique used to characterize metallothionein adduct formation was mass spectrometry. Mass spectrometry affords a sensitive and selective mode of analysis. In particular, electrospray ionization mass spectrometry (ESI) was utilized for these experiments. Electrospray ionization is very useful for samples containing large, non-volatile molecules such as proteins (Prange, 2002).

For electrospray ionization, a solution containing the sample and electrolytes is pumped through a metal capillary needle that has a high potential applied to it. The electric field at the tip of the capillary needle generates an aerosol of charged droplets. These droplets are attracted to an orifice in the interface that carries an opposite charge from that of the capillary needle. As the droplets flow toward the orifice, the droplets desolvate, leaving behind charged ions. 
Electrospray ionization is a soft ionization technique that keeps the molecular structure of the proteins intact. Thus, molecular and structural information can be obtained.

Once adduct formation is established, the next step is to locate the site of adduct formation. This can be done in a variety of ways. One approach is to use molecular modeling to predict where adduct formation occurs. The modeling predictions are then confirmed experimentally. For example, the protein could be digested and sequenced to verify the modeling results.

Molecular modeling has become an important and powerful tool in understanding the structure of proteins. Molecular structure conformations are simulated using a molecular mechanics approach with force field based calculations. The force field represents energy calculations that contain information such as bond lengths, bond angles, and torsion angles. Reactions can be modeled in silico to view predicted information on atomic motions that can not be readily observed experimentally. Comparison to experimental data, where available, is then done to confirm modeling predictions. Structural studies of metallothionein have been done using molecular modeling (Rigby, 2004), and modeling has also been used to study drug interactions with metallothionein (Szilagyi, 2000).

As previously stated, the objective of these experiments was to form covalent adducts between styrene oxide and trans-phenylpropylene oxide with metallothionein. The formation of adducts between metallothionein and styrene oxide or transphenylpropylene oxide could further demonstrate the function of metallothionein in the body. Metallothionein-styrene oxide adducts may also provide a basis for the development of biomarkers for epoxide exposure. 


\section{Methods and Materials}

Chemicals and Reagents. Metallothionein-I from rabbit liver was purchased from Sigma Chemical. The metal content of Metallothionein-I from rabbit liver is approximately $7 \%$ of cadmium and zinc. Metallothionein-I is essentially salt free. Styrene oxide and trans-phenylpropylene oxide were purchased from Aldrich Chemical. Dithiothreitol, guanidine hydrochloride, and Tris buffer were purchased from Sigma Chemical. Trifluoroacetic acid and ethylenediaminetetraacetic acid (EDTA) were purchased from Fisher Chemical. Acetonitrile and methanol were HPLC grade and were purchased from Fisher Chemical. Methyl 4-nitrobenzenesulfonate was purchased from Aldrich Chemical.

The one milliliter $\mathrm{C} 18$ solid phase extraction cartridges were purchased from Varian Corporation. The PD-10 desalting columns were purchased from Amersham Biosciences.

Metal Removal Process. apo-Metallothionein was obtained through a treatment process of the purchased metallothionein-I based on a literature method (Zaia, 1998). apo-MT-I was prepared by adding trifluoroacetic acid solution $(0.02 \%)$ to MT-I in water $(100 \mu \mathrm{g}, 16 \mu \mathrm{M})$. The sample was thoroughly mixed and allowed to sit at room temperature for one-half hour. The metals were removed by solid phase extraction. A one milliliter $\mathrm{C}-18$ extraction cartridge was first conditioned by allowing two onemilliliter portions of methanol to flow through the cartridge, followed by two onemilliliter portions of water. The sample was loaded onto the cartridge and allowed to flow completely through. The cartridge was then washed with two two-hundred microliter washes of $0.1 \%$ trifluoroacetic acid. The sample was eluted from the cartridge by one two-hundred microliter elution of an acetonitrile: water (30:70) mixture.

Adduct Formation. The procedure for forming adducts between metallothionein and styrene oxide was a simple mixture step based on a method for forming glutathionestyrene oxide adducts (Ishida, 1989). Styrene oxide (500 $\mu \mathrm{g}, 4.2 \mathrm{mM})$ was added to a MT-I sample $(100 \mu \mathrm{g}, 16 \mu \mathrm{M})$. The sample was rocked for one-half hour at room temperature. Following the mixing step, the samples were taken through the metal 
removal process. Twenty microliters of $10 \mathrm{mM}$ ammonium acetate was added to the sample and mixed before infusion into the mass spectrometer.

The method for forming adducts between apo-metallothionein and styrene oxide was similar to the procedure for metallothionein. Styrene oxide $(500 \mu \mathrm{g}, 4.2 \mathrm{mM})$ was added to the apo-metallothionein $(100 \mu \mathrm{g}, 16 \mu \mathrm{M})$ sample and mixed for one-half hour at room temperature. In a test to increase adduct formation, DTT $(0.046 \mathrm{mg}, 0.3 \mathrm{mM})$ was added to a portion of the samples. Twenty microliters of $10 \mathrm{mM}$ ammonium acetate was added to the final sample and mixed before infusion into the mass spectrometer.

The method for forming adducts between metallothionein and transphenylpropylene oxide was a simple mixture step. trans-phenylpropylene oxide $(0.04$ $\mathrm{mg}, 0.3 \mathrm{mM})$ was added to the metallothionein sample $(100 \mu \mathrm{g}, 16 \mu \mathrm{M})$. The sample was rocked for one-half hour at room temperature and was allowed to stand for 24 additional hours at room temperature. The samples were then taken through the metal removal process. Twenty microliters of $10 \mathrm{mM}$ ammonium acetate was added to the sample and mixed before infusion into the mass spectrometer.

Mass Spectral Analysis of Adduct Formation. A Finnigan Deca LCQ quadrupole ion trap mass spectrometer was used for adduct sample analysis. The source utilized electrospray ionization. Ions were monitored in the positive ionization mode. The mass analyzer was an ion trap. The samples were infused into the mass spectrometer at a flow rate of $7 \mu \mathrm{L} / \mathrm{min}$. The heated capillary temperature was $160^{\circ} \mathrm{C}$. The spray voltage was set to $5.21 \mathrm{kV}$, and the capillary voltage was at $50 \mathrm{~V}$. The sheath gas flow rate was 39 $\mathrm{mL} / \mathrm{min}$. MS/MS conditions were 2 amu range on the parent mass and the collision energy range was from $30-75 \%$.

Molecular Modeling. For the modeling of the styrene oxide adduct, a search was first executed at the RCSB Protein Data Bank and only rabbit metallothionein-2 (alpha and beta domain) was found. Next a search was done at the Swiss Prot site for rabbit metallothionein-1. Rabbit metallothionein-1 was located, but there was no accompanying PDB file. Several proteins were considered as surrogates for the structure for rabbit metallothionein-1, however, mouse metallothionein-1 was chosen as the 
starting structure. All cysteine residues are conserved between mouse MT-1 and rabbit MT-1, and mouse MT-1 has $84 \%$ homology with rabbit MT-1. See Table 2.1 for comparison of rabbit and mouse metallothionein-1.

Accelrys' program Insight II was used for the molecular modeling experiments. The downloaded PDB files of mouse metallothionein-1 were separated into the alpha (Cterminus) and beta (N-terminus) domains. See Figures 2.1 and 2.2 for the model of the alpha and beta domains of mouse metallothionein-1.

Insight II was used to model the styrene oxide ligand. Figure 2.3 shows the structures for both styrene oxide and trans-phenylpropylene oxide. The builder module was utilized. An optimization was run on the structure to achieve a low-energy confirmation. First the docking procedure using the Affinity module was followed for docking styrene oxide to the mouse metallothionein-1 alpha domain followed by the beta domain. The styrene oxide was positioned close to the cysteine residues. The active site was defined for an area of a $6 \AA$ radius. The docking was simulated in a vacuum with a dielectric constant of 1 , and ten structures were accepted. Docking simulations were conducted using a dielectric constant of 80 to simulate water, and ten more structures were accepted. The initial minimization was 100 steps before the simulated annealing calculations. In the simulated annealing estimation the initial temperature was $500{ }^{\circ} \mathrm{K}$ cooling down to $300^{\circ} \mathrm{K}$. The final minimization was 1000 steps using the conjugate gradient method.

Alkylation and Digestion. To verify the modeling results and to experimentally determine where the styrene oxide adducted to the metallothionein, alkylation and digestion of the protein was necessary. Alkylation of the protein was required because of a tendency of the cysteine residues to form disulfide bonds, resulting in possible formation of false fragments after digestion. The alkylation and digestion procedure utilized was based on previous work (Hunziker, 1991) with modifications (Yu, 1995).

Samples for MT and MT-SO were prepared as previously described with the exception that a desalting column followed by lyophilization was utilized in place of the C18 solid phase extraction for metal removal. 
For the metal removal using the desalting column, the column was first equilibrated with $20 \mathrm{~mL}$ of $0.1 \%$ (v/v) trifluoroacetic acid (TFA). The sample was then loaded onto the desalting column and eluted with $3.5 \mathrm{~mL}$ of $0.1 \%(\mathrm{v} / \mathrm{v})$ TFA. Following elution, the sample was lyophilized.

The lyophilized protein was dissolved in $5 \mathrm{~mL}$ of buffer solution consisting of $6 \mathrm{M}$ guanidine $\mathrm{HCl}, 0.5 \mathrm{M}$ tris/ $\mathrm{HCl}$, and $5 \mathrm{mM}$ EDTA, $\mathrm{pH} 8.6$, containing $10 \mathrm{mM}$ DTT. The samples were then immersed in water bath at $37^{\circ} \mathrm{C}$ for 2 hours. After incubation, 272 $\mathrm{mM}$ methyl 4-nitrobenzenesulfonate $(2.5 \mathrm{~mL})$ was added to the samples and they were again immersed in a water bath at $37^{\circ} \mathrm{C}$ for an additional 6 hours. The reaction was stopped by acidification to $\mathrm{pH} 2.0$ by addition of $20 \% \mathrm{TFA}$, and the mixture was applied to a desalting column, and the eluant lyophilized.

The proteins were digested after dissolving the lyophilized samples in $0.1 \mathrm{M}$ ammonium bicarbonate at $1 \mathrm{mg} / \mathrm{mL}$. Trypsin was added at a 1:50 (w/w) trypsin/protein ratio. The samples were then incubated in a water bath at $37^{\circ} \mathrm{C}$ for 2 hours. The digests were refrigerated, desalted as above, and lyophilized.

Mass Spectral Analysis. A Finnigan Deca LCQ quadrupole ion trap mass spectrometer was used for digest analysis. The source utilized electrospray ionization. Ions were monitored in the positive ionization mode. The samples were infused into the mass spectrometer at a flow rate of $7 \mu \mathrm{L} / \mathrm{min}$. The heated capillary temperature was 160 ${ }^{\circ} \mathrm{C}$. The spray voltage was set to $5.21 \mathrm{kV}$, and the capillary voltage was at $50 \mathrm{~V}$. The sheath gas flow rate was $39 \mathrm{~mL} / \mathrm{min}$.

Molecular Modeling. To further elucidate which cysteine residue was the site of adduct formation, molecular modeling experiments were conducted after the alkylation and digestion experiments. Using Insight II, styrene oxide adducts for both cysteine residues 44 and 48 were modeled using the downloaded mouse MT-1 file and assimilating the styrene oxide ligand to the cystene residues in question. Next, a minimization using a combination of steepest descent and conjugate gradient for 1000 iterations was performed on each complex, and the resultant energies of the complexes were calculated. 


\subsection{Results}

The major ions in the positive ion ESI spectrum of metallothionein were $1671(+4$ charge state), 1337 ( +5 charge state), and 1115 ( +6 charge state). This calculates to be a molecular weight of approximately 6685 for metallothionein (Fig. 3.1). The major charge distribution for MT was at the +6 charge state. After styrene oxide was adducted there was a shift in the spectrum such that the major ions became 1834 ( +4 charge state), 1457 ( +5 charge state), and 1230 (+6 charge state) (Fig. 3.2).

When metallothionein is taken through the metal removal process the mass spectrum simplifies. The major ions in the spectrum after metal removal were $1561(+4$ charge state), 1249 ( +5 charge state), 1041 ( +6 charge state), and 892 ( +7 charge state). This calculates to be a molecular weight of approximately 6245 (Fig. 3.3). The major charge distribution for apo-MT was at the +5 charge state.

After adduct formation with styrene oxide, the MT sample went through the metal removal process to simplify the spectrum in an attempt to determine the stoichiometry of the styrene oxide to metallothionein reaction. At various charge states $(+4$ to +7$)$, varying amounts of styrene oxide were adducted to the metallothionein (Fig. 3.4).

After adduct formation with trans-phenylpropylene oxide, the MT sample went through the metal removal process to simplify the spectrum in an attempt to see how much trans-phenylpropylene oxide was adducted to the metallothionein. At various charge states $(+5$ to +7$)$, varying amounts of trans-phenylpropylene oxide were adducted to the metallothionein (Fig. 3.5). The mass comparisons of protein versus adducted protein are outlined in Table 3.1.

After adduct formation with styrene oxide, apo-MT was monitored at various charge states $(+4$ to +6$)$, and styrene oxide was shown to be adducted to the apometallothionein (Fig. 3.6).

In an attempt to increase adduct formation between apo-MT and styrene oxide, dithiothreitol (DTT) was added to the reaction. Dithiothreitol is a reducing agent that minimizes the formation of disulfide bonds between cysteine residues and thereby 
potentially increases adduct formation with styrene oxide by keeping the cysteine residues reduced and available for adduct formation. The results indicated better adduct formation after the addition of DTT (Table 3.1).

MS/MS experiments were conducted after adduct formation. Solutions of the non-adducted protein and adducted protein were infused separately into the mass spectrometer and subjected to varying amounts of collision energy. The change in mass from precursor to product ion were similar ( $\mathrm{m} / \mathrm{z}$ approximately 288$)$ for the non-adducted protein and adducted protein for both SO and PPO (Table 3.2). When using increasing collision energies $(30,60$, and $75 \%)$ similar fragment patterns were also achieved. See Figures 3.7, 3.8, and 3.9 for MS/MS of metallothionein-I and the SO and PPO adducts at the +5 charge state.

For molecular modeling of metallothionein-I/styrene oxide adduct formation, the output from the runs was examined using the Insight II analysis module for alpha and beta domain adducts. The beta domain total energies were consistently lower than the alpha domain total energies (Table 3.3). According to the original hypothesis for the project the lower total energies should point to where adducts would most likely form. Next, protein-ligand bond distances were considered in adduct formation.

The protein-ligand bond distances considered were from the docking simulation where the dielectric constant was set to 80 , simulating water. The experimental reaction was in water and so this particular simulation was chosen. Protein-ligand bond distances of less than $6 \AA$ from a cysteine residue were considered possible sites for adduct formation. For several of the structures multiple cysteine residues met the criteria to be sites of adduct formation. Table 3.4 gives the residue site and protein-ligand bond distances for the Alpha domain. As can be seen from the table, A6, A7, and A18 (cysteine residues 36, 37, and 48 respectively) stand out for the most potential sites of adduct formation. In addition A14 (cysteine residue 44) also could be a site for adduct formation as the protein-ligand bond distances for 2 of the 3 matches were less than $4 \AA$.

Table 3.5 gives the protein-ligand bond distances for the beta domain. Only A5 (cysteine residue 5) is a potential site for adduct formation. Most calculated protein- 
ligand bond distances for the beta domain were too long to support adduct formation with a cysteine site.

For the alkylation of the cysteine residues, various alkylating agents were tested. Full alkylation of metallothionein-I was achieved using N-ethylmaleimide. One very important factor in not incorporating N-ethylmaleimide into the final alkylation and digestion procedure was that the reaction is reversible (Shaw, 1997). The next alkylating agent tested was iodoacetamide (Bernhard, 1991). Iodoacetamide, however, only partially alkylated the protein. The final alkylating agent tested was methyl 4nitrobenzenesulfonate. The alkylation with methyl 4-nitrobenzenesulfonate was still only partially complete, but to a greater extent than with the iodoacetamide.

The experimental confirmation of adduct formation suggests that formation occurs in the 44-51 peptide fragment of MT-1, which has an expected $\mathrm{m} / \mathrm{z}$ of 825 (Table 3.6). When this fragment is successfully alkylated, the $m / z$ of 867 corresponds to the three cysteine residues in the fragment being methylated (Fig. 3.10). Ions were observed at the expected $\mathrm{m} / \mathrm{z}$ of 867 for the control sample (unadducted MT-I). An ion was observed at 973 for the SO adducted sample (Fig. 3.11). This ion corresponds to the addition of one SO and two methyl groups to the MT-I fragment 44-51 (Fig. 3.12). These experimental results were repeated and yielded the same result. This fragment result supports the modeling results for cysteine residue 48 , or possibly cysteine residue 44.

The results from modeling the styrene oxide adducts on cysteine residues 44 and 48 of the alpha domain support the hypothesis of preferential adduct formation on residue 48 (see Fig. 3.13). After optimization, the van der Waals energy for adduct formation at cysteine residue 44 was $487.6 \mathrm{kcal} / \mathrm{mol}$, as compared to $120.7 \mathrm{kcal} / \mathrm{mol}$ for cysteine residue 48. The total energy for adduct formation at cysteine residue 44 was 504.1 $\mathrm{kcal} / \mathrm{mol}$, as compared to $302.4 \mathrm{kcal} / \mathrm{mol}$ for cysteine residue 48 .

\subsection{Discussion}

A characteristic of electrospray ionization is the spectrum represents an intact 
molecule carrying differing numbers of charges. These ions arise from the molecule having multiple protonations or attachment of multiple cations (in positive ion mode). A shift in the charge state is possible, and can be the result of a change in solvent polarity or a loss of non-covalently bound atoms from the analyte resulting in a lower charge state distribution (Cole, 2000). A small charge state distribution shift was observed for MT versus apo-MT with a shift from the +6 to the +5 charge state, which could be due to loss of metals.

For styrene oxide, it was not determined in these experiments which carbon binds to the metallothionein. Either 1-phenyl-2-hydroxyethyl-MT or 2-phenyl-2-hydroxyethylMT could have formed.

Metallothionein forms adducts with styrene oxide (SO) and transphenylpropylene oxide (PPO). Adducts with $\mathrm{SO}$ and $\mathrm{PPO}$ were detected at all charge states identified for MT-I.

An additional experiment was conducted at this time under the previously described conditions to attempt to form adducts between styrene and metallothionein. MS experiments indicated no adduct formation between styrene and MT, as the spectrum remained unchanged from the control.

apo-Metallothionein forms an adduct with SO. For apo-metallothionein, the addition of reducing agent, DTT, showed increase of adduct formation with SO. In the presence of DTT the stoichiometry of styrene oxide to metallothionein increased to 3-4 molecules versus 1-2 molecules in the absence of DTT. apo-Metallothionein adducts with SO were detected at all charge states identified.

MS/MS experiments indicated the covalent nature of adduct formation of $\mathrm{SO} / \mathrm{PPO}$ with metallothionein/apo-metallothionein. The change in mass from precursor to product ion is similar ( $\mathrm{m} / \mathrm{z}$ approximately 288 ) for the non-adducted and adducted protein for both SO and PPO. When using increasing collision energies $(30,60$, and 75\%) similar fragment patterns are achieved (Table 3.7), although the signal intensity lessens with increased collision energy. If the bond were non-covalent in nature, the loss of the styrene oxide mass would be expected at each charge state based on lower 
dissociation energy associated with fragmenting non-covalent adducts in comparison with the energy required to fragment covalent bonds. The dissociation energy for a covalent C-N bond is $305 \mathrm{~kJ} / \mathrm{mol}$, and the dissociation energy for a covalent C-S bond is $280 \mathrm{~kJ} / \mathrm{mol}$. A loss corresponding to styrene oxide was not observed in any of the MS/MS experiments.

The identity of the MS/MS product ion loss ( $\mathrm{m} / \mathrm{z}$ approximately 288$)$ is still not known. It is possible that the fragment is a -Met-Asp- fragment from the N-terminal end of metallothionein. Mammalian metallothioneins are characteristically $\mathrm{N}$-acetylated (Beattie, 1999), and the presence of an acetyl group could yield a loss corresponding to an observed $\mathrm{m} / \mathrm{z}$ loss of 288 with the formation of a ketene (Fig. 3.14).

The data from the molecular modeling lead to the conclusion that even though the energy is lower for the beta domain, adduct formation is more likely to occur in the alpha domain for mouse metallothionein-1. Four potential sites for adduct formation in the alpha domain were identified at cysteine residues 36, 37, 44 and 48 . These simulations did not narrow the reactive site of the protein to a single cysteine residue.

A similar experiment was performed by Szilagyi and Fenselau using rat metallothionein-2 to form adducts with nitrogen mustard drugs (Szilagyi, 2000). The simulations also used Insight II. The cysteine residues at 33 and 48 in the alpha domain were found to be the most favorable for adduct formation. The criteria used were lower energy and bond lengths less than $4 \AA$.

Our calculations agree with the prediction of Szilagyi and Fenselau in that cysteine residue 48 is a favored site for adduct formation. In contrast cysteine residue 33 was not identified as a favored reaction site. Besides the obvious differences in proteins and ligands between the experiments, Szilagyi and Fenselau used explicit solvent information in their simulation. Their system was surrounded by water. This calculation method provides a better evaluation of electrostatic forces which are important in ligandreceptor interactions. Future experiments could be repeated using explicit solvent information to verify the prediction of the active sites for metallothionein.

The alkylation and protein digestion experiments indicate that adduct formation 
occurs in the 44-51 peptide fragment of MT-1. Masses were observed at the expected $\mathrm{m} / \mathrm{z}$ of 867 for the control sample (unadducted MT), and a mass was observed at 973 for the SO adducted sample indicating the addition of one SO. The experimental results are consistent with the modeling results. Further work to clarify adduct formation to the exact residue could be done using liquid chromatography with tandem mass spectrometry to separate peptide fragments and fully sequence them.

The results from modeling the styrene oxide adducts on cysteine residues 44 and 48 of the alpha domain again support the hypothesis of preferential adduct formation on residue 48 . The residue with the lower total energy, cysteine residue 48 , would be the more favorable site for adduct formation. In addition, from the modeling information, adduct formation on cysteine residue 48 is less sterically hindered than on cysteine residue 44 as the van der Waals energy differences indicate.

The stable nature of the adduct formation with SO and PPO with metallothionein and apo-metallothionein makes them ideal candidates as potential biomarkers.

\section{Summary and Conclusions}

Metallothioneins (MT) are intracellular, low molecular weight, cysteine-rich proteins that efficiently sequester epoxides, such as the genotoxic styrene metabolite, styrene oxide (SO). We hypothesized that covalent adduct formation by the ring-opening of SO and its homologue, trans-phenylpropylene oxide (PPO), with MT forms stable complexes that may serve as potential biomarkers for exposure to styrenes. MT was reacted with SO or PPO in water. After the MT reaction with SO and PPO, metals were removed prior to mass spectral analysis. Mass spectra were obtained under electrospray ionization conditions with positive-ion detection in an ion trap mass spectrometer. Mass spectra of MT-SO and MT-PPO showed that adducts were present in all charge states detected. MS/MS analysis indicated the covalent nature of the complexation. Further experiments were conducted to determine the site of adduct formation. Molecular modeling utilizing Insight II was used to predict the most likely site of adduct formation. Alkylation and digestion of MT and MT-SO were used to locate the peptide fragment 
where adduct formation occurred and additionally confirm the modeling results. The likeliest cysteine residue for adduct formation was residue 48 in the alpha domain of MTI. MT-styrene oxide adducts can provide a basis for the development of biomarkers for exposure to epoxides. 
Table 2.1: Amino Acid Sequence Comparison of Mouse to Rabbit MT-1

\begin{tabular}{|c|c|c|c|c|c|}
\hline \multicolumn{3}{|c|}{ Beta Domain } & \multicolumn{3}{|c|}{ Alpha Domain } \\
\hline Residue* & Type (mouse-1) & $\begin{array}{c}\text { Type } \\
\text { (rabbit-1) }\end{array}$ & Residue* & Type (mouse-1) & $\begin{array}{c}\text { Type } \\
\text { (rabbit-1) }\end{array}$ \\
\hline A1 (1) & MET & MET & A1 (31) & LYS & LYS \\
\hline A2 (2) & ASP & ASP & A2 (32) & SER & SER \\
\hline A3 (3) & PRO & PRO & A3 (33) & CYS & CYS \\
\hline A4 (4) & ASN & ASN & A4 (34) & CYS & CYS \\
\hline A5 (5) & CYS & CYS & A5 (35) & SER & SER \\
\hline A6 (6) & SER & SER & A6 (36) & CYS & CYS \\
\hline A7 (7) & CYS & CYS & A7 (37) & CYS & CYS \\
\hline A8 (8) & SER & ALA & A8 (38) & PRO & PRO \\
\hline A9 (9) & THR & THR & A9 (39) & VAL & ALA \\
\hline A10 (10) & GLY & GLY & A10 (40) & GLY & GLY \\
\hline A11 (11) & GLY & ASN & A11 (41) & CYS & CYS \\
\hline A12 (12) & SER & SER & A12 (42) & SER & THR \\
\hline A13 (13) & CYS & CYS & A13 (43) & LYS & LYS \\
\hline A14 (14) & THR & THR & A14 (44) & CYS & CYS \\
\hline A15 (15) & CYS & CYS & A15 (45) & ALA & ALA \\
\hline A16 (16) & THR & ALA & A16 (46) & GLN & GLN \\
\hline A17 (17) & SER & SER & A17 (47) & GLY & GLY \\
\hline A18 (18) & SER & SER & A18 (48) & CYS & CYS \\
\hline A19 (19) & CYS & CYS & A19 (49) & VAL & ILE \\
\hline A20 (20) & ALA & LYS & A20 (50) & CYS & CYS \\
\hline A21 (21) & CYS & CYS & $\mathrm{A} 21(51)$ & LYS & LYS \\
\hline A22 (22) & LYS & LYS & A22 (52) & GLY & GLY \\
\hline A23 (23) & ASN & GLU & A23 (53) & ALA & ALA \\
\hline A24 (24) & CYS & CYS & A24 (54) & ALA & SER \\
\hline A25 (25) & LYS & LYS & A25 (55) & ASP & ASP \\
\hline A26 (26) & CYS & CYS & A26 (56) & LYS & LYS \\
\hline A27 (27) & THR & THR & A27 (57) & CYS & CYS \\
\hline A28 (28) & SER & SER & A28 (58) & THR & SER \\
\hline A29 (29) & CYS & CYS & A29 (59) & CYS & CYS \\
\hline A30 (30) & LYS & LYS & A30 (60) & CYS & CYS \\
\hline & & & A31 (61) & ALA & ALA \\
\hline
\end{tabular}

*The A designation is domain position, and the (number) designation is total protein position. (Swiss-Prot, 2003) 


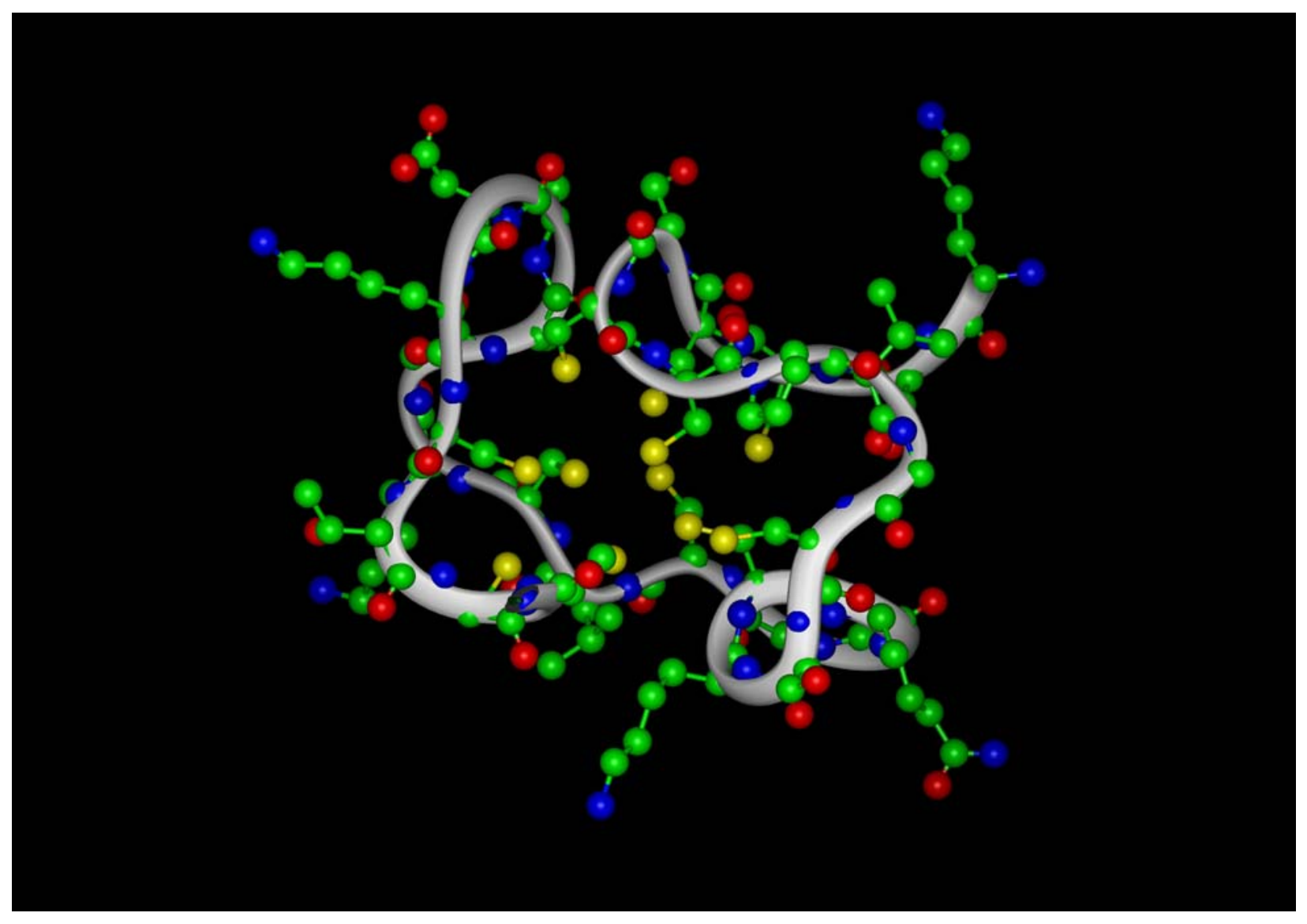

Figure 2.1 Alpha Domain of Mouse Metallothionein-I (RSCB, 2003) 


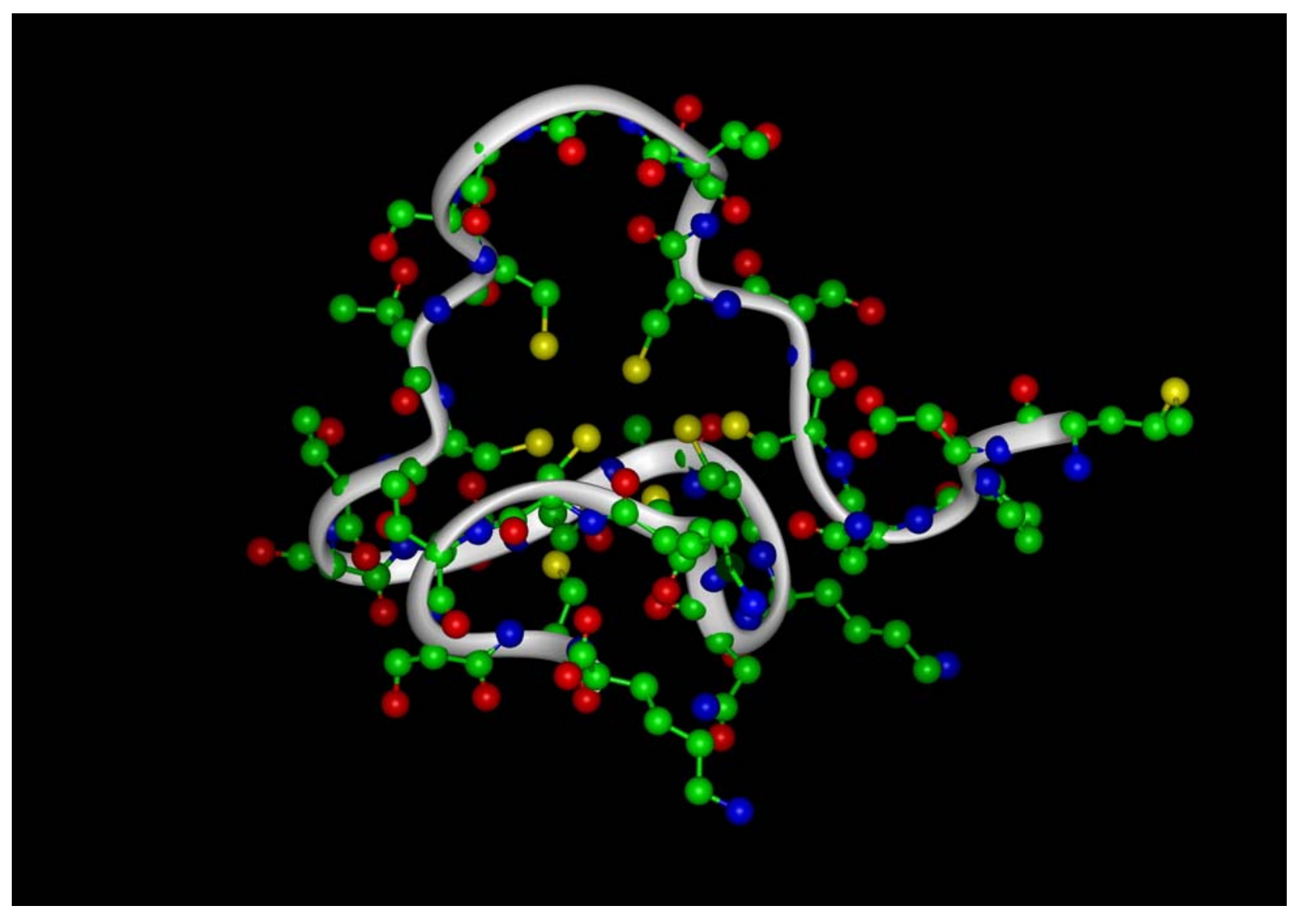

Figure 2.2 Beta Domain of Mouse Metallothionein-I (RCSB, 2003) 
Figure 2.3 Styrene Oxide and trans-Phenylpropylene Oxide



\section{Styrene Oxide [SO]}

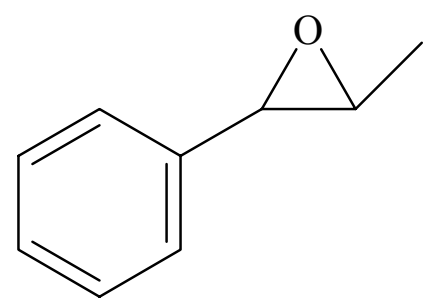

trans-Phenylpropylene Oxide [PPO] 
Table 3.1: Adduct Formation for MT-I with Styrene Oxide and trans-phenylpropylene oxide

\begin{tabular}{|c|c|c|c|c|c|}
\hline Sample & $\begin{array}{c}\text { Adduct } \\
\text { Formation }\end{array}$ & $\begin{array}{l}+4 \text { charge } \\
\text { state }(\mathrm{m} / \mathrm{z})\end{array}$ & $\begin{array}{l}+5 \text { charge } \\
\text { state }(m / z)\end{array}$ & $\begin{array}{l}+6 \text { charge } \\
\text { state }(m / z)\end{array}$ & $\begin{array}{l}+7 \text { charge } \\
\text { state }(m / z)\end{array}$ \\
\hline MT & ND & 1671 & 1337 & 1114.8 & 948.7 \\
\hline MT-SO & $\begin{array}{l}+2 \mathrm{SO} \\
+3 \mathrm{SO} \\
+4 \mathrm{SO} \\
+5 \mathrm{SO} \\
+6 \mathrm{SO} \\
+7 \mathrm{SO} \\
\end{array}$ & $\begin{array}{c}\text { ND } \\
1621 \\
1681 \\
1711 \\
1741 \\
1771 \\
\end{array}$ & $\begin{array}{l}1297 \\
1321 \\
1345 \\
1369 \\
1393 \\
1417 \\
\end{array}$ & $\begin{array}{l}1081 \\
1101 \\
1121 \\
1141 \\
1161 \\
1181 \\
\end{array}$ & $\begin{array}{l}\text { ND } \\
944 \\
961 \\
978 \\
\text { ND } \\
\text { ND }\end{array}$ \\
\hline МТ-PРO & $\begin{array}{l}+1 \mathrm{PPO} \\
+2 \mathrm{PPO} \\
+3 \mathrm{PPO} \\
+4 \mathrm{PPO}\end{array}$ & $\begin{array}{l}1594 \\
1628 \\
1661 \\
1695 \\
\end{array}$ & $\begin{array}{l}1276 \\
1303 \\
1329 \\
1356 \\
\end{array}$ & $\begin{array}{l}1063 \\
1086 \\
1108 \\
1130 \\
\end{array}$ & $\begin{array}{l}911 \\
930 \\
950 \\
969 \\
\end{array}$ \\
\hline apoMT & $\mathrm{n} / \mathrm{a}$ & 1561 & 1249 & 1041 & 892 \\
\hline apoMT-SO & $\begin{array}{l}+1 \mathrm{SO} \\
+2 \mathrm{SO}\end{array}$ & $\begin{array}{l}1591 \\
1621\end{array}$ & $\begin{array}{l}1273 \\
1297\end{array}$ & $\begin{array}{l}1061 \\
1081\end{array}$ & $\begin{array}{l}\text { ND } \\
\text { ND }\end{array}$ \\
\hline apoMT-SO & $\begin{array}{l}+1 \mathrm{SO} \\
+2 \mathrm{SO}\end{array}$ & $\begin{array}{l}1591 \\
1621\end{array}$ & $\begin{array}{l}1273 \\
1297\end{array}$ & $\begin{array}{l}1061 \\
1081\end{array}$ & $\begin{array}{l}\text { ND } \\
\text { ND }\end{array}$ \\
\hline & $\begin{array}{l}+3 \mathrm{SO} \\
+4 \mathrm{SO}\end{array}$ & $\begin{array}{l}1651 \\
1681\end{array}$ & $\begin{array}{l}1322 \\
1345\end{array}$ & $\begin{array}{c}1101 \\
\mathrm{n} / \mathrm{a}\end{array}$ & $\begin{array}{l}\text { ND } \\
\text { ND }\end{array}$ \\
\hline
\end{tabular}

ND $=$ not detected 
Table 3.2: Product vs. Precursor Ions for Various Charge States of Metallothionein Adducts

\begin{tabular}{c|cccccc}
\hline \multirow{3}{*}{ Sample } & \multicolumn{2}{c}{$+\mathbf{+ 5}$ charge state } & \multicolumn{1}{c}{$+\mathbf{6}$ charge state } & \multicolumn{2}{c}{$+\mathbf{7}$ charge state } \\
\cline { 2 - 7 } MT & Precursor & Product & Precursor & Product & Precursor & Product \\
\cline { 2 - 6 } MT-SO & 1249 & 1191.5 & 1041 & 993.3 & 892 & 851.4 \\
\cline { 2 - 7 } & 1297 & 1239.6 & 1081 & 1033.3 & ND & ND \\
\cline { 2 - 7 } MT-PPO & 1345 & 1287.5 & 1141 & 1093.3 & & 870.6 \\
& 1276 & 1218.5 & 1063 & 1016.1 & 911 & \\
& 1303 & 1244.8 & 1086 & 1038.1 & & \\
\cline { 2 - 7 } & & & & &
\end{tabular}

ND $=$ not detected 
Table 3.3: Total Energies of Final structures for Alpha and Beta Adducts

\begin{tabular}{|c|c|c|c|c|}
\hline $\begin{array}{c}\text { Mouse-I } \\
\text { Structure }\end{array}$ & $\begin{array}{c}\text { Energy } \\
\text { Alpha (vacuum) } \\
(\mathrm{kcal} / \mathrm{mol})\end{array}$ & $\begin{array}{c}\text { Energy } \\
\text { Beta (vacuum) } \\
(\mathrm{kcal} / \mathrm{mol})\end{array}$ & $\begin{array}{c}\text { Energy } \\
\text { Alpha (water) } \\
(\mathrm{kcal} / \mathrm{mol})\end{array}$ & $\begin{array}{c}\text { Energy } \\
\text { Beta (water) } \\
(\mathrm{kcal} / \mathrm{mol})\end{array}$ \\
\hline 1 & 437.4590 & 369.8630 & 344.4770 & 307.1810 \\
\hline 2 & 440.9780 & 370.9230 & 346.6740 & 308.4490 \\
\hline 3 & 441.3430 & 372.1730 & 349.5620 & 309.0830 \\
\hline 4 & 442.6950 & 372.6940 & 350.0410 & 310.7720 \\
\hline 5 & 444.3390 & 373.9290 & 352.2860 & 313.9340 \\
\hline 6 & 444.4920 & 374.6710 & 353.2320 & 314.0260 \\
\hline 7 & 444.7340 & 375.8580 & 355.6810 & 315.9610 \\
\hline 8 & 447.8670 & 376.2370 & 355.9450 & 315.9990 \\
\hline 9 & 450.4120 & 376.5850 & 359.0570 & 316.3760 \\
\hline 10 & 455.1700 & 383.9900 & 359.4490 & 318.9410 \\
\hline
\end{tabular}


Table 3.4: Optimal Protein-Ligand Distances in the $\alpha$-Domain of less than $6 \AA$

\begin{tabular}{|c|c|c|c|c|c|c|}
\hline \multicolumn{9}{|c|}{ Alpha mouse-1 } \\
\hline $\begin{array}{c}\text { Structur } \\
\text { e }\end{array}$ & $\begin{array}{c}\text { Residue/ } \\
\text { length }\end{array}$ & $\begin{array}{c}\text { Residue/ } \\
\text { length }\end{array}$ & $\begin{array}{c}\text { Residue/ } \\
\text { length }\end{array}$ & $\begin{array}{c}\text { Residue/ } \\
\text { length }\end{array}$ & $\begin{array}{c}\text { Residue/ } \\
\text { length }\end{array}$ & $\begin{array}{c}\text { Residue/ } \\
\text { length }\end{array}$ \\
\hline 1 & $\mathrm{~A} 4 / 2.55$ & $\mathrm{~A} 7 / 4.58$ & $\mathrm{~A} 14 / 3.06$ & $\mathrm{~A} 18 / 4.10$ & & \\
\hline 2 & $\mathrm{~A} 4 / 4.31$ & $\mathrm{~A} 6 / 5.87$ & $\mathrm{~A} 7 / 2.99$ & $\mathrm{~A} 14 / 4.52$ & $\mathrm{~A} 29 / 5.96$ & $\mathrm{~A} 30 / 5.42$ \\
\hline 3 & $\mathrm{~A} 18 / 5.91$ & & & & & \\
\hline 4 & $\mathrm{~A} 18 / 4.82$ & & & & & \\
\hline 5 & $\mathrm{~A} 6 / 5.65$ & & & & & \\
\hline 6 & $\mathrm{~A} 6 / 3.06$ & $\mathrm{~A} 7 / 5.87$ & $\mathrm{~A} 20 / 4.00$ & $\mathrm{~A} 29 / 4.28$ & & \\
\hline 7 & $\mathrm{NONE}$ & & & & & \\
\hline 8 & $\mathrm{~A} 6 / 5.49$ & $\mathrm{~A} 14 / 3.18$ & $\mathrm{~A} 18 / 4.55$ & $\mathrm{~A} 30 / 4.38$ & & \\
\hline 9 & $\mathrm{NONE}$ & & & & & \\
\hline 10 & $\mathrm{~A} 7 / 5.39$ & $\mathrm{~A} 27 / 4.72$ & & & & \\
\hline
\end{tabular}


Table 3.5: Optimal Protein-Ligand Distances in the $\beta$-Domain of less than $6 \AA$

\begin{tabular}{|c|c|c|c|c|}
\hline Structure & $\begin{array}{c}\text { Residue/ } \\
\text { length }\end{array}$ & $\begin{array}{c}\text { Residue/ } \\
\text { length }\end{array}$ & $\begin{array}{c}\text { Residue/ } \\
\text { length }\end{array}$ & $\begin{array}{c}\text { Residue/ } \\
\text { length }\end{array}$ \\
\hline 1 & A5/4.22 & A7/4.23 & A24/5.86 & A26/3.06 \\
\hline 2 & $\mathrm{~A} 5 / 4.75$ & & & \\
\hline 3 & $\mathrm{~A} 5 / 4.43$ & $\mathrm{~A} 13 / 4.97$ & $\mathrm{~A} 26 / 4.40$ & \\
\hline 4 & $\mathrm{NONE}$ & & & \\
\hline 5 & $\mathrm{NONE}$ & & & \\
\hline 6 & $\mathrm{NONE}$ & & & \\
\hline 7 & $\mathrm{~A} 5 / 4.61$ & & & \\
\hline 8 & $\mathrm{NONE}$ & & & \\
\hline 9 & $\mathrm{NONE}$ & & & \\
\hline 10 & $\mathrm{NONE}$ & & & \\
\hline
\end{tabular}


Table 3.6: Metallothionein-I Peptide Mapping

\begin{tabular}{|c|c|c|}
\hline Peptide & Unalkylated $\mathrm{m} / \mathrm{z}$ & Alkylated $m / z$ \\
\hline $\begin{array}{c}1-20 \\
(\text { MDPNCSCATGNSCTCASSCK) }\end{array}$ & 1983 & 2053 \\
\hline $\begin{array}{l}21-22 \\
(\mathrm{CK})\end{array}$ & 249 & 263 \\
\hline $\begin{array}{l}23-25 \\
(\mathrm{ECK})\end{array}$ & 378 & 392 \\
\hline $\begin{array}{c}26-31 \\
(\mathrm{CTSCKK})\end{array}$ & 669 & 697 \\
\hline $\begin{array}{c}32-43 \\
\text { (SCCSCCPAGCTK) }\end{array}$ & 1162 & 1232 \\
\hline $\begin{array}{c}44-51 \\
(\mathrm{CAQGCICK})\end{array}$ & 825 & $\begin{array}{c}867(+3 \text { methyl }) \\
973(+2 \text { methyl and }+1 S O)\end{array}$ \\
\hline $\begin{array}{c}52-56 \\
\text { (GASDK) }\end{array}$ & 477 & 477 \\
\hline $\begin{array}{c}57-61 \\
(\mathrm{CSCCA})\end{array}$ & 486 & 528 \\
\hline
\end{tabular}

(Swiss-Prot, 2003) 
Table 3.7: Collision Energy Comparison of Precursor vs. Product Ions at +5 Charge State

\begin{tabular}{|c|c|c|c|c|}
\hline Sample & $\begin{array}{c}\text { Precursor } \\
\mathbf{m} / \mathbf{z}\end{array}$ & $\begin{array}{c}\text { Collision } \\
\text { Energy }\end{array}$ & $\begin{array}{c}\text { Product Ions } \\
\mathbf{m} / \mathbf{z}\end{array}$ & $\begin{array}{c}\text { Signal } \\
\text { Intensity }\end{array}$ \\
\hline \multirow{2}{*}{ MT } & 1248.9 & $30 \%$ & 1191.7 & $5.8 \times 10^{5}$ \\
\cline { 3 - 5 } & & $60 \%$ & 1191.9 & $1.7 \times 10^{5}$ \\
\cline { 3 - 5 } & \multirow{2}{*}{ MT-SO } & $75 \%$ & 1191.7 & $4.5 \times 10^{4}$ \\
\cline { 3 - 5 } & \multirow{2}{*}{1297.6} & $30 \%$ & 1239.3 & $1.0 \times 10^{5}$ \\
\cline { 3 - 5 } & & $60 \%$ & 1239.1 & $4.1 \times 10^{4}$ \\
\cline { 3 - 5 } & & $75 \%$ & 1240.0 & $2.7 \times 10^{4}$ \\
\hline
\end{tabular}


Figure 3.1 Mass Spectrum of Metallothionein-I

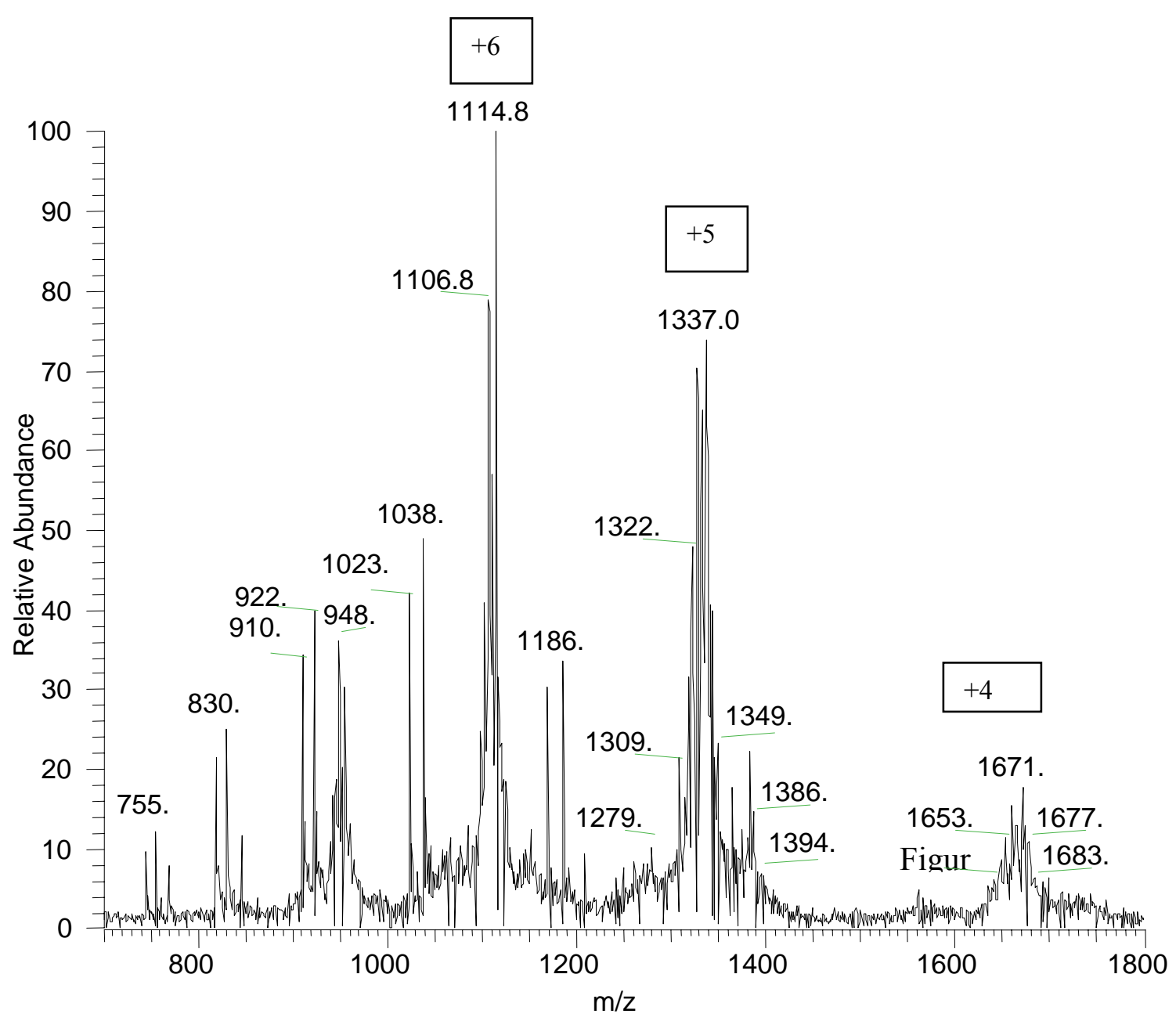


Figure 3.2 Mass Spectrum of Metallothionein-I/Styrene oxide Adduct

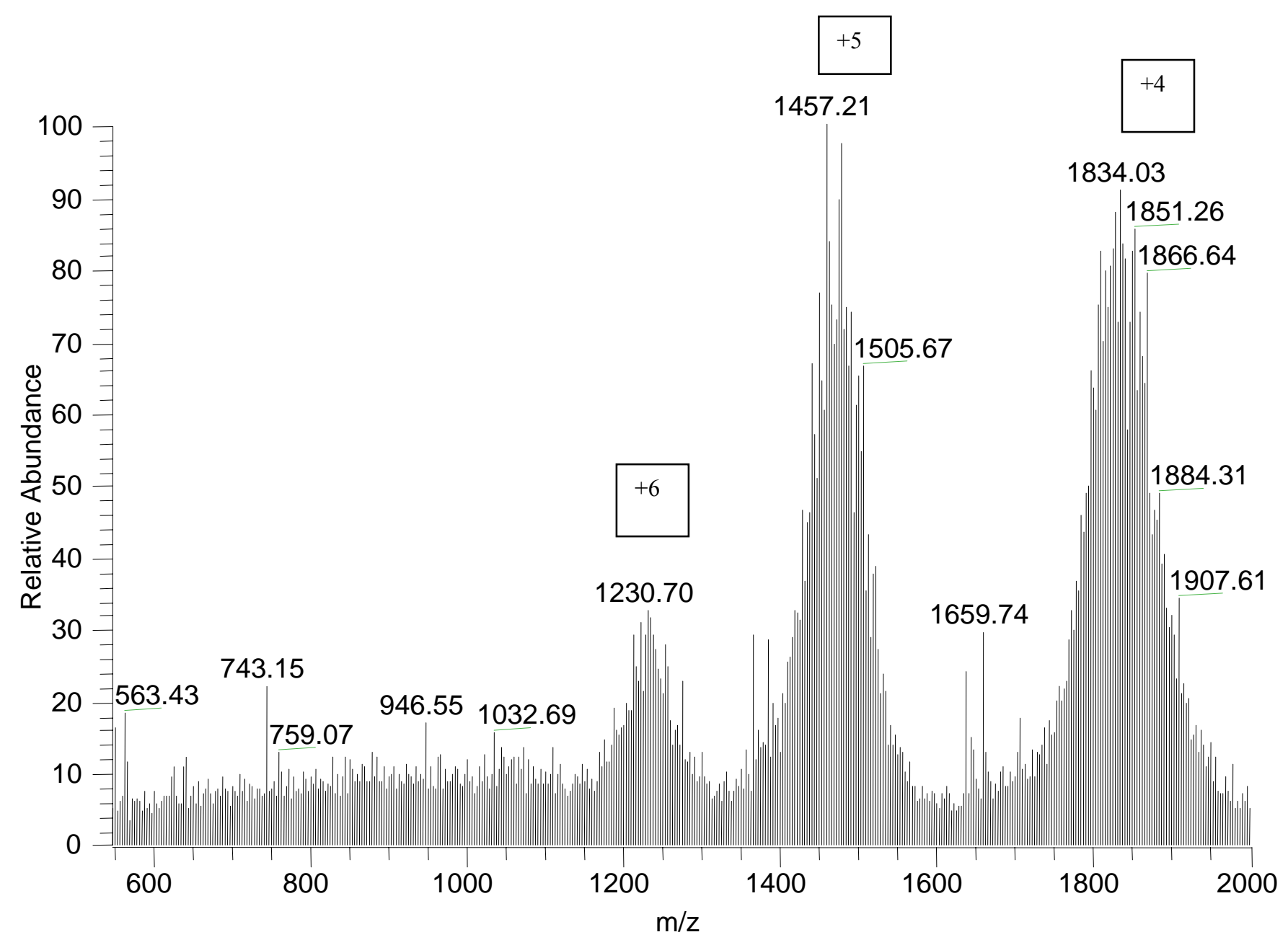


Figure 3.3 Mass Spectrum of apo-Metallothionein-I

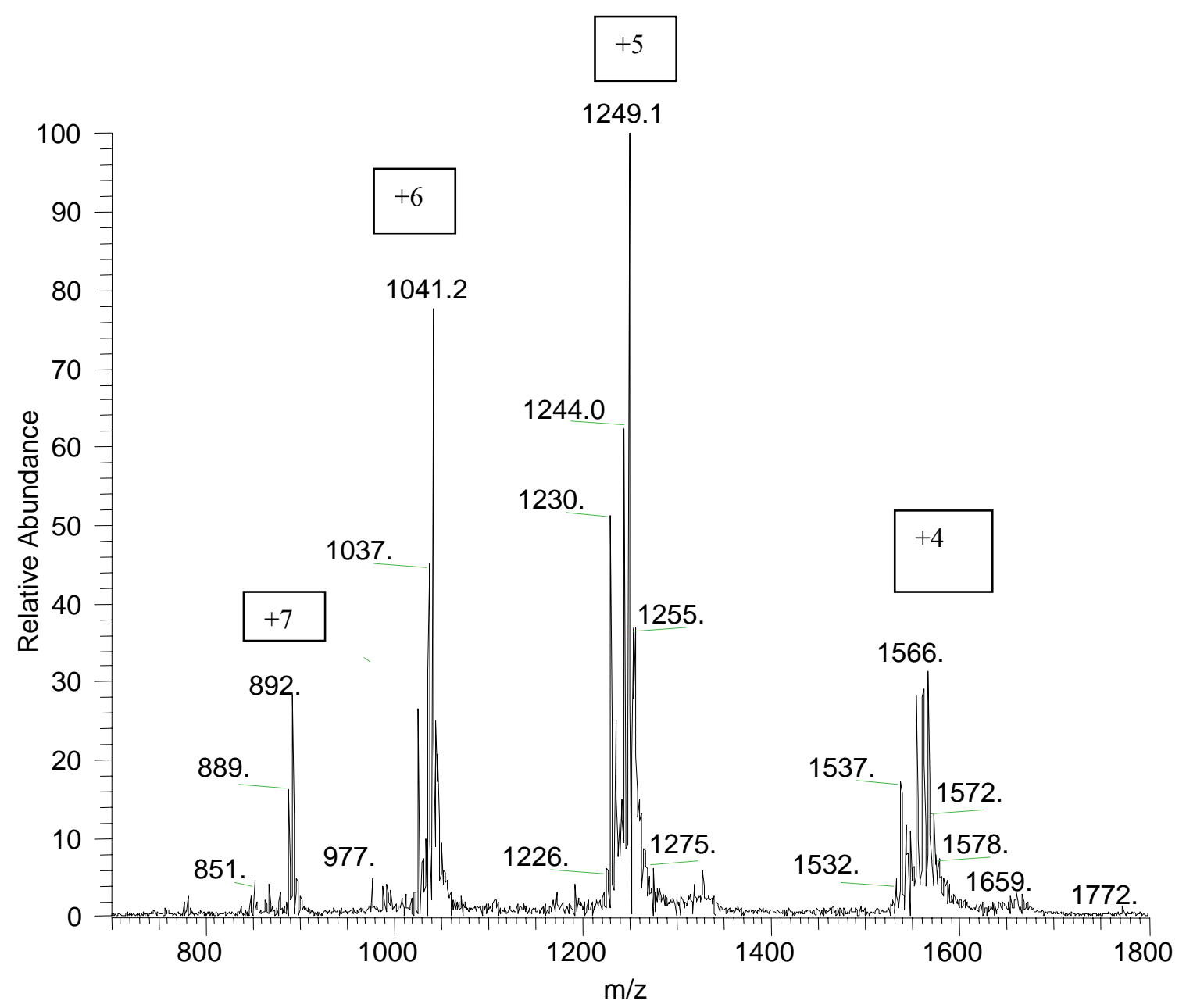


Figure 3.4 Mass Spectrum of MT-I/SO Adduct after metal Removal




Figure 3.5 Mass Spectrum of MT-I/PPO Adduct after Metal Removal

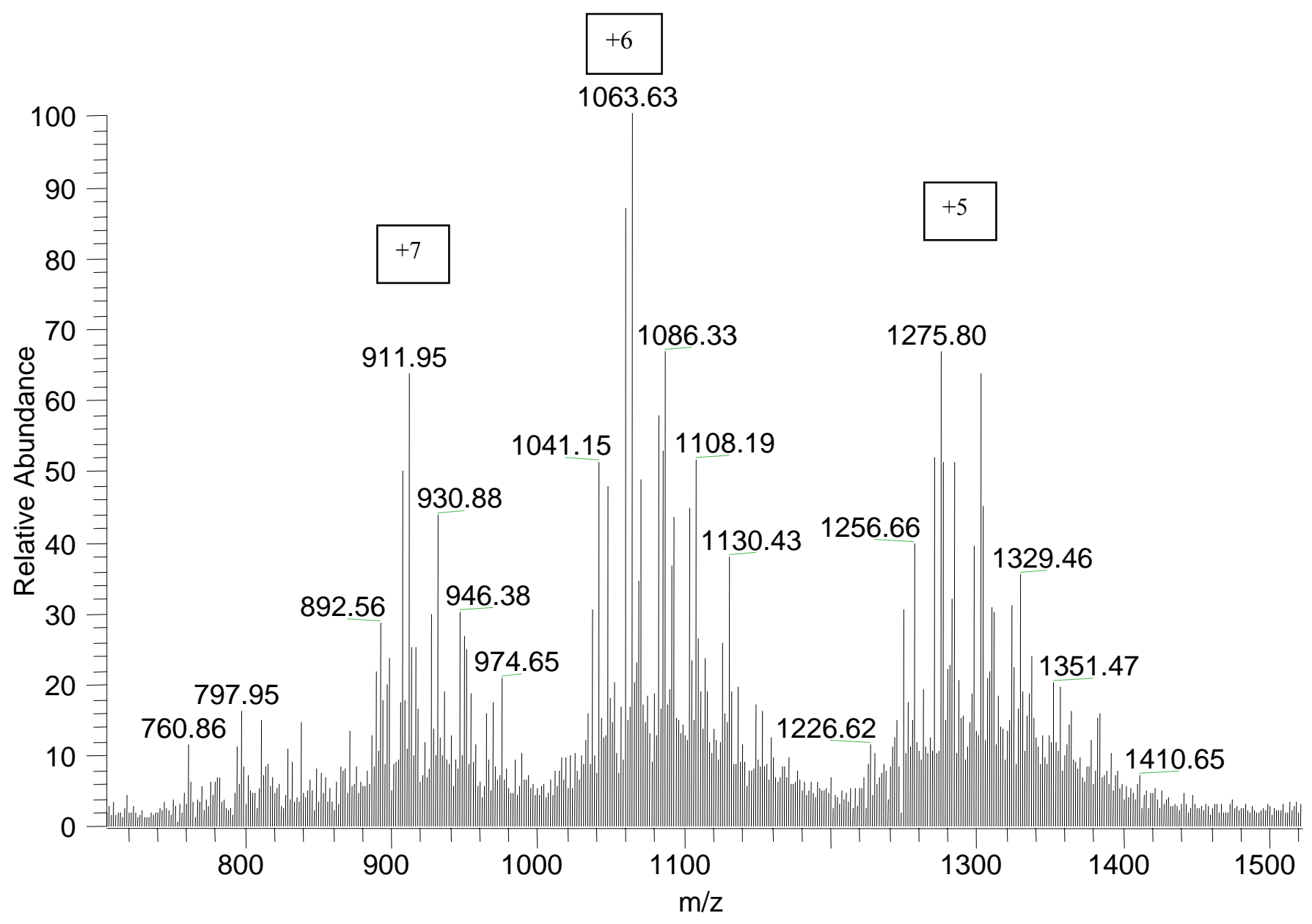


Figure 3.6 Mass Spectrum of apoMT-I/SO Adduct

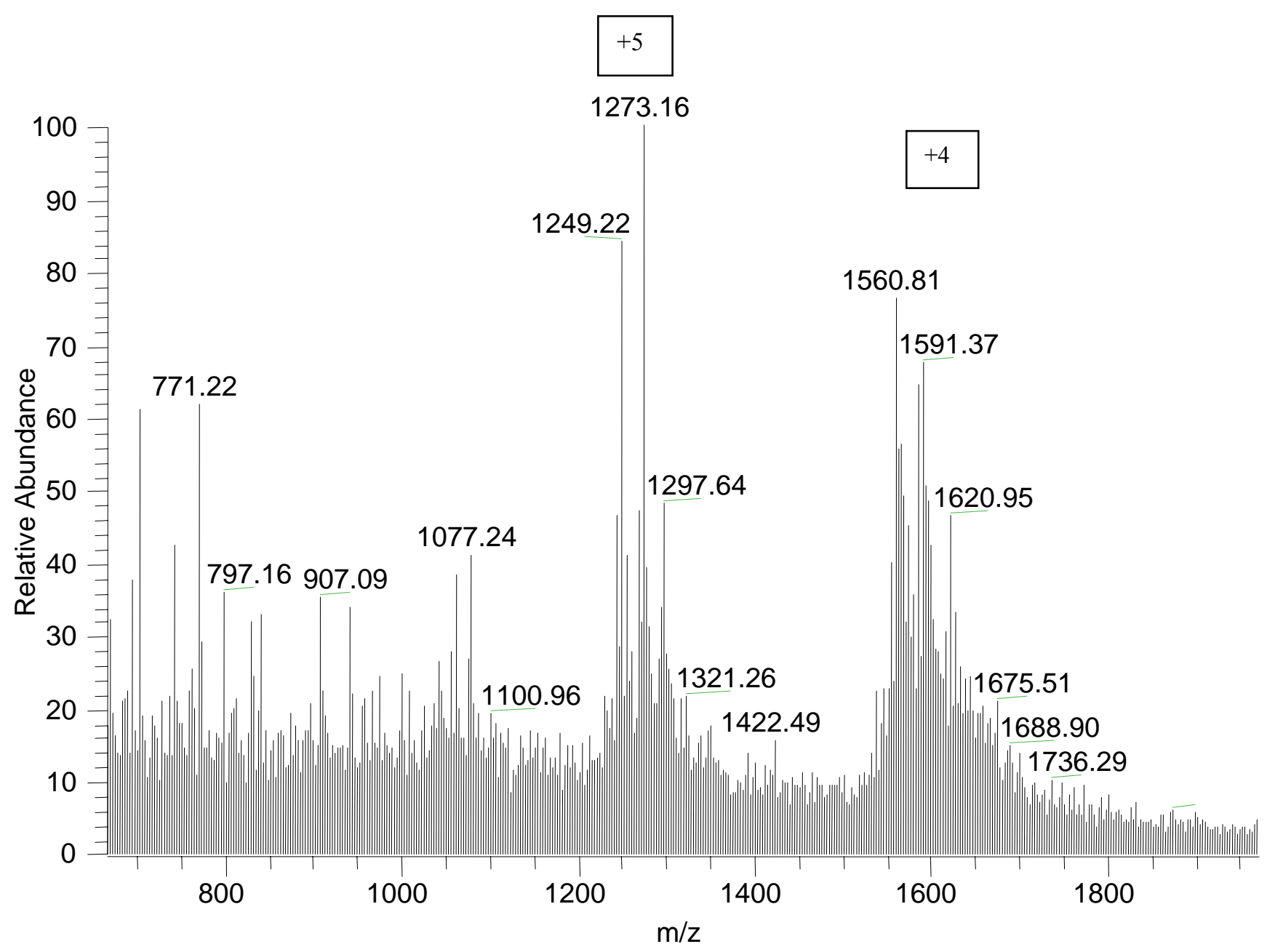


Figure 3.7 MS/MS of Metallothionein-I at +5 Charge State (Precursor 1249)

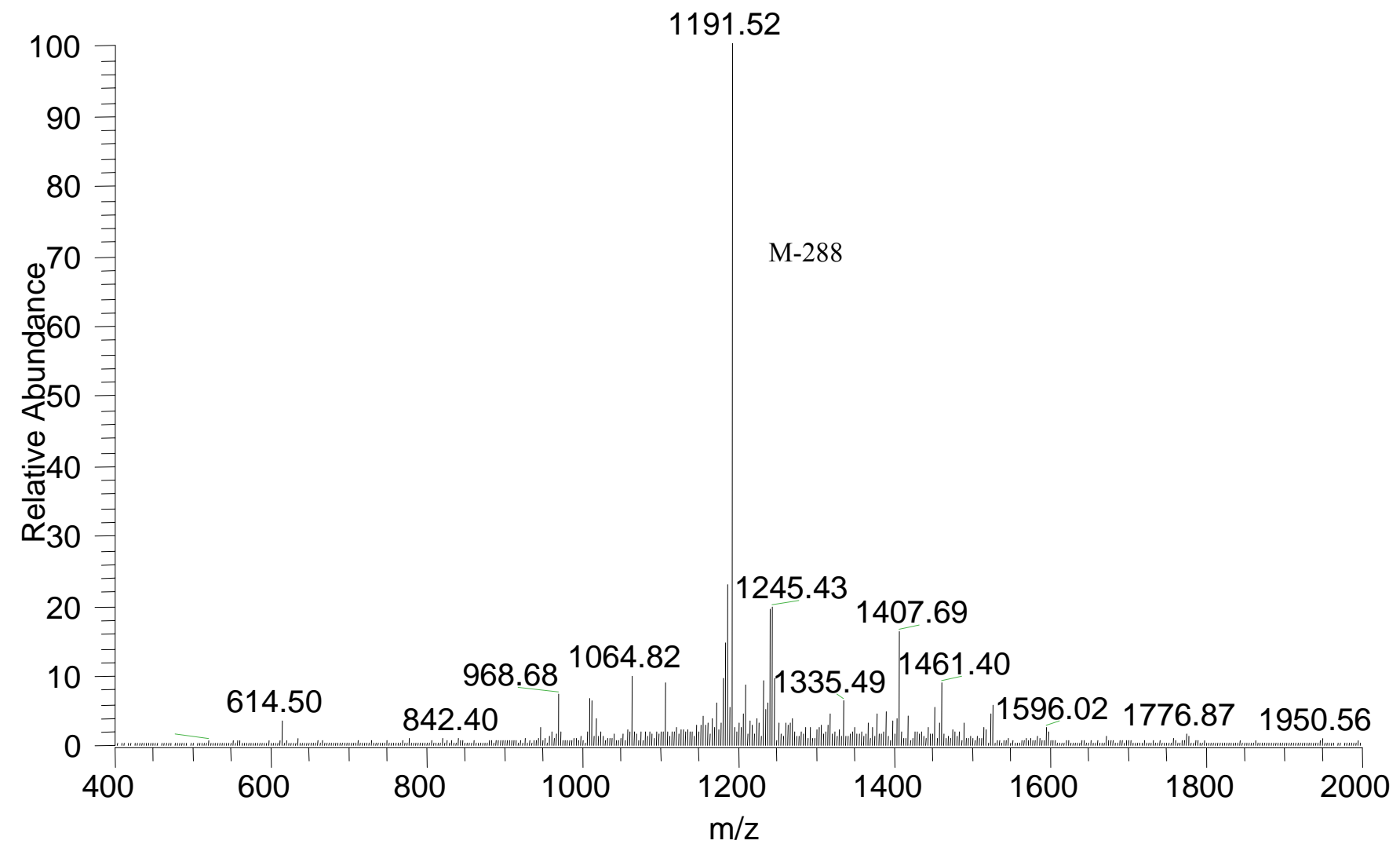


Figure 3.8 MS/MS of MT-I/SO Adduct at +5 Charge State

(Precursor 1273)

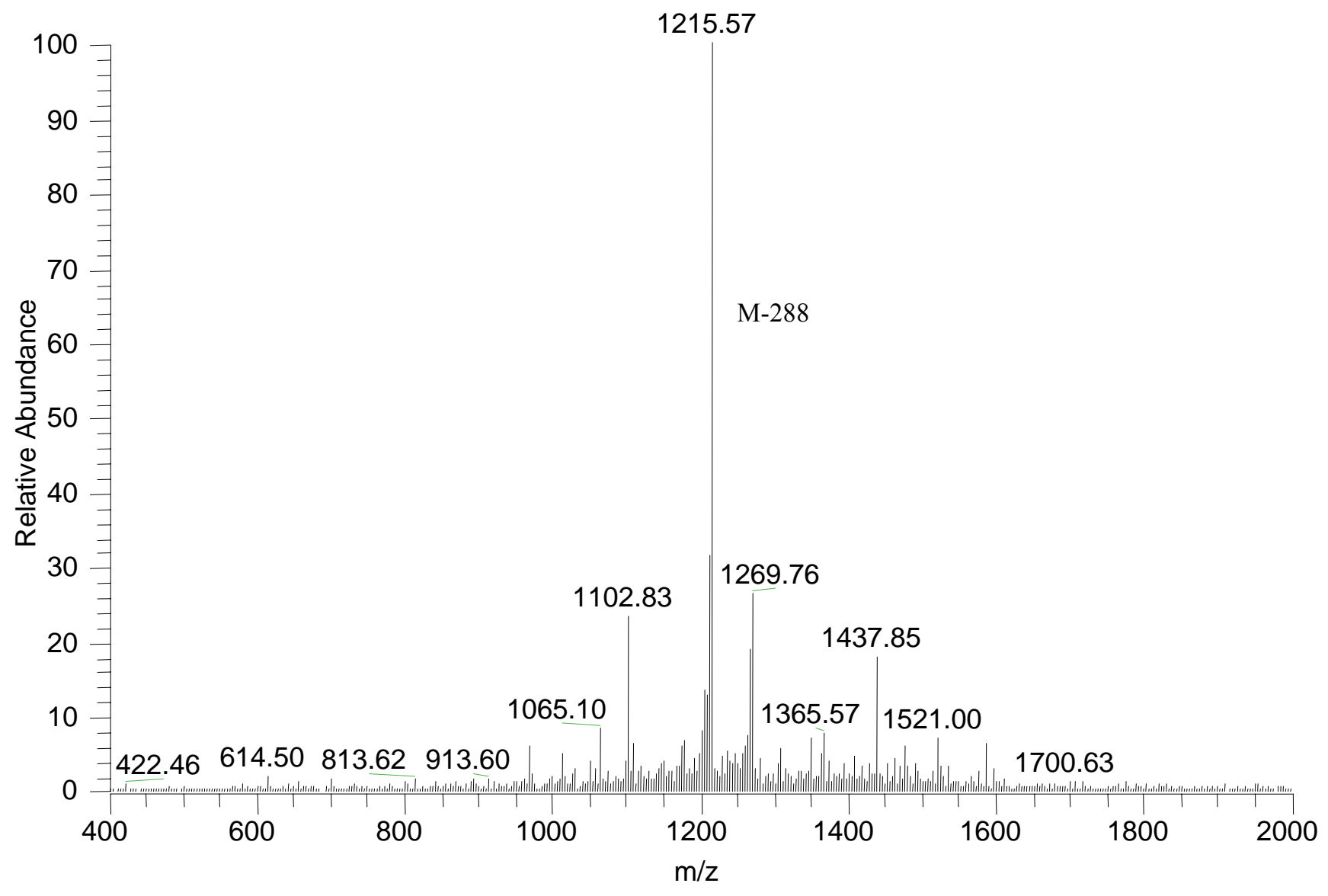


Figure 3.9 MS/MS of MT-I/PPO Adduct at +5 Charge State

(Precursor 1276)

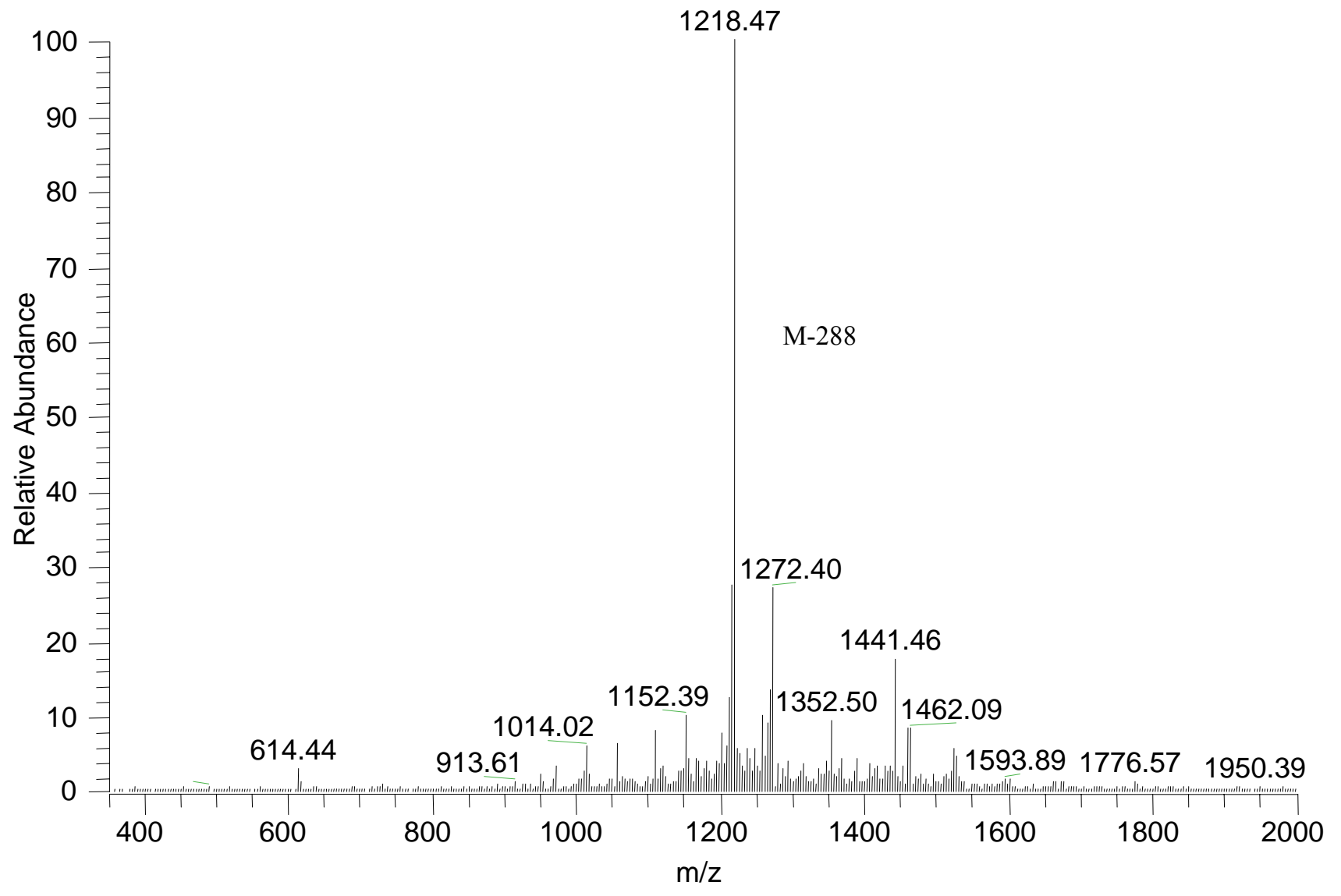


Figure 3.10 Mass Spectrum of Metallothionein-I Digest

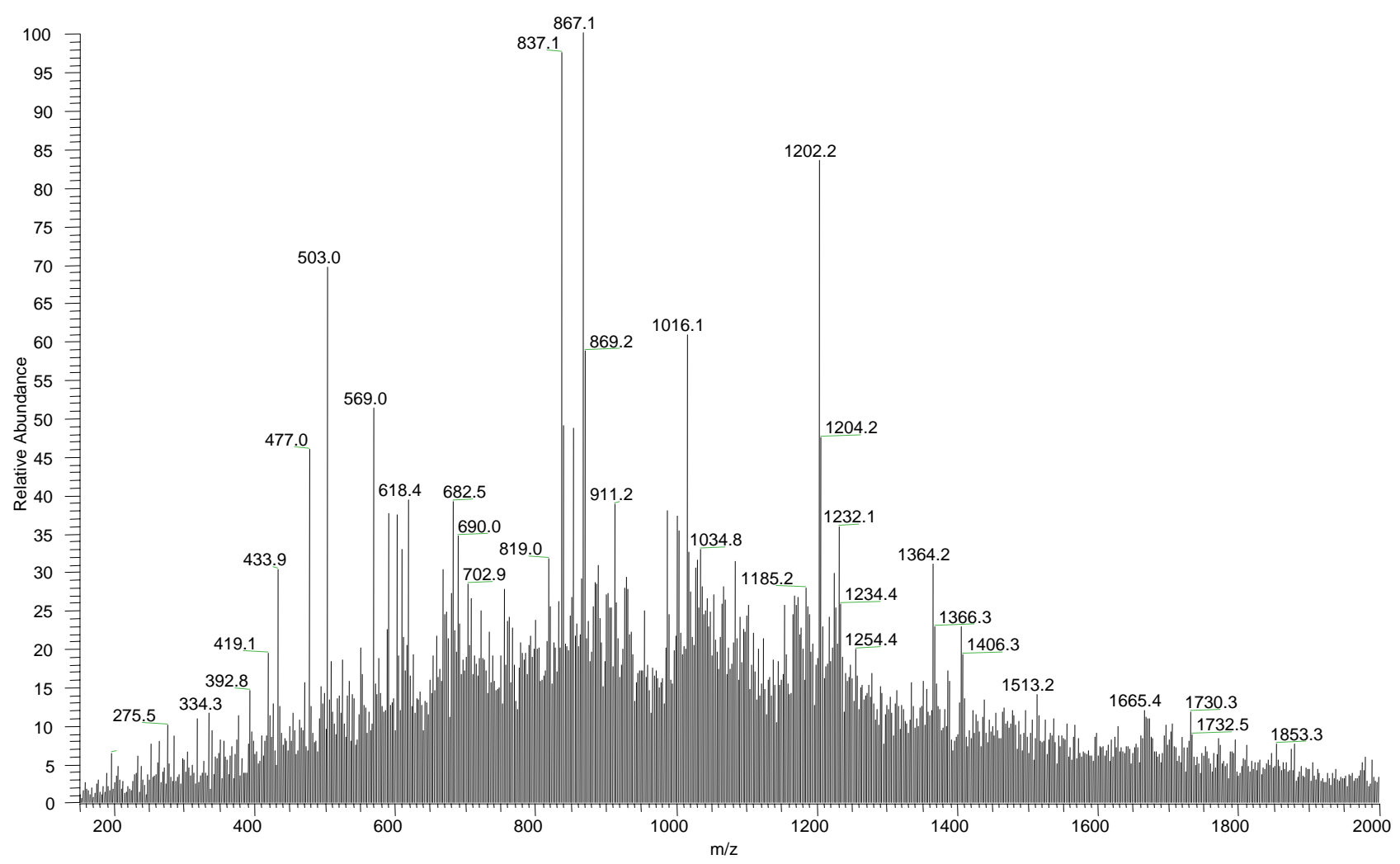


Figure 3.11 Mass Spectrum of MT-I/SO Adduct Digest

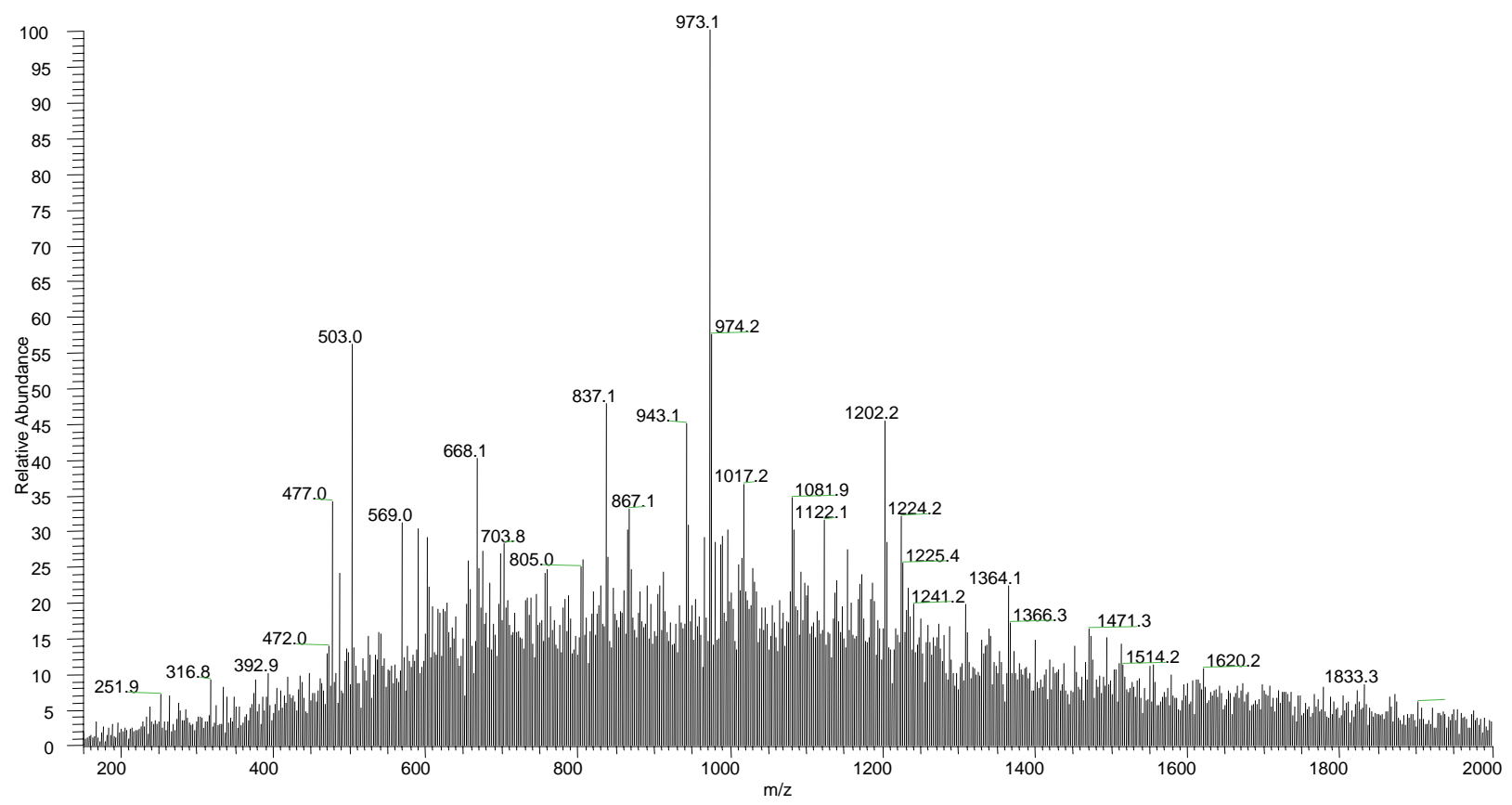


Figure 3.12 Proposed Structure for SO Adducted Peptide Fragment 44-51 for MT

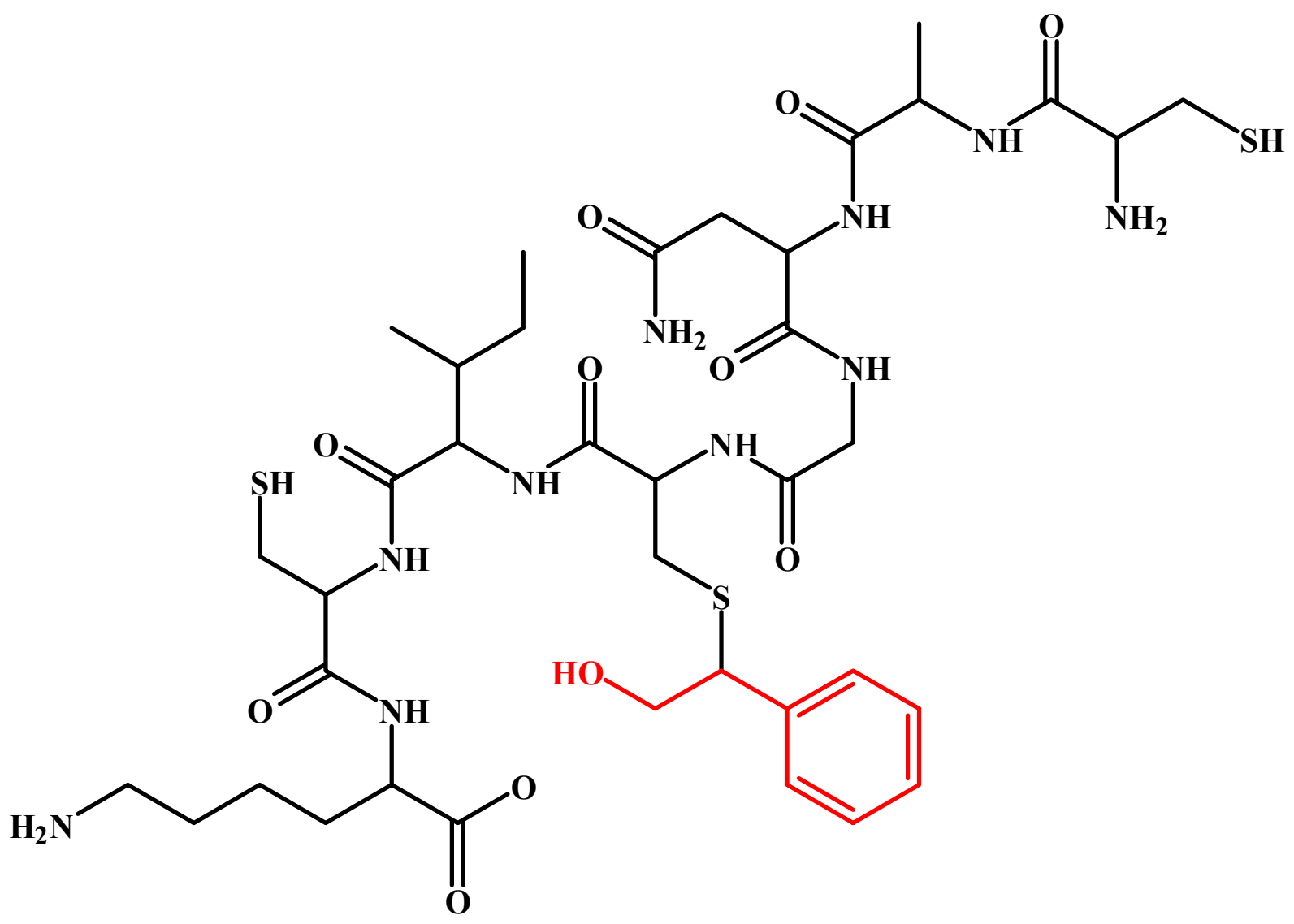


Figure 3.13 Proposed Metallothionein-I/Styrene oxide Adduct at Cysteine Residue 48

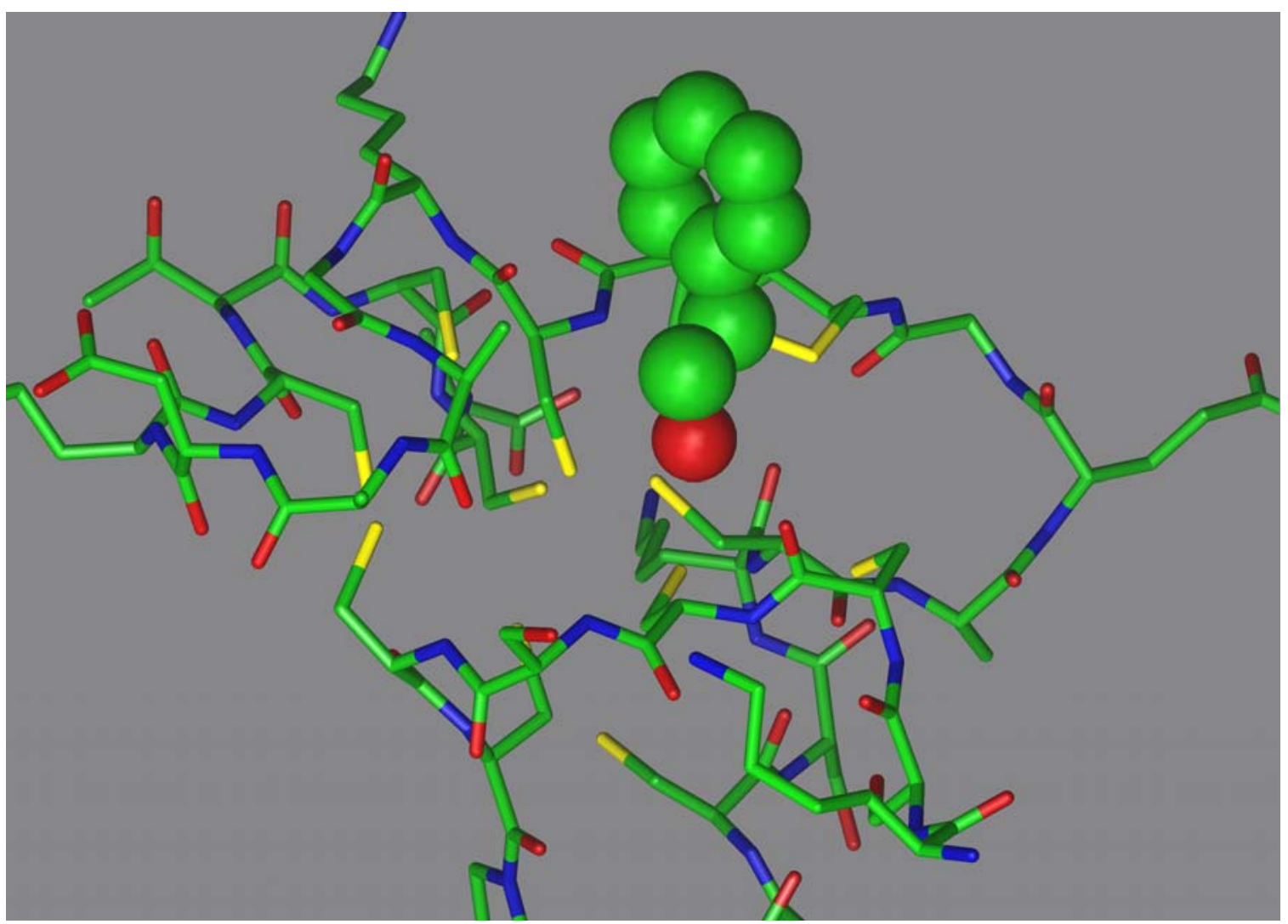


Figure 3.14 Proposed Structure of MS/MS Fragment Corresponding to Loss of 288

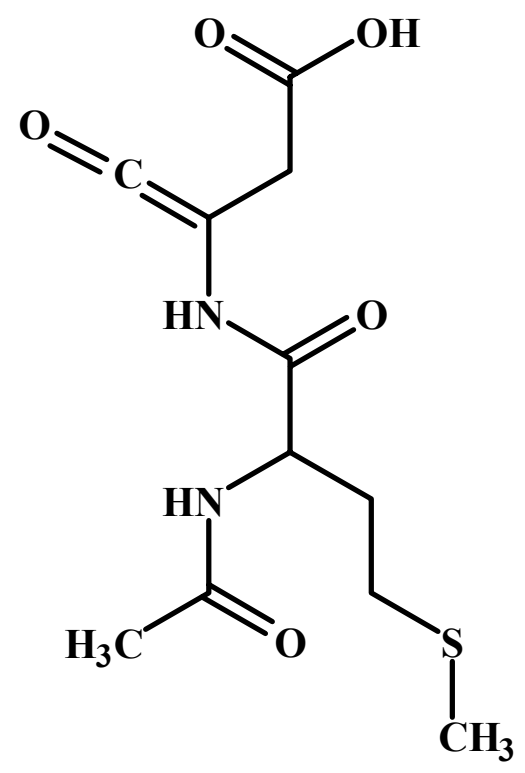




\section{Reference List}

Antoine M, Fabris D, and Fenselau C: Covalent sequestration of the nitrogen mustard mechlorethamine by metallothionein. Drug Metabolism and Disposition 1998; (26), 921-926.

Beattle J, Wood A, Duncan G: Rat metallothionein-2 contains N-acetylated and unacetylated isoforms. Electrophoresis 1999; (20), 1613-1618.

Bernhard W: Differential modification of metallothionein with iodoacetamide. Methods in Enzymology 1991; (205), 426-433.

Dabrio M, Rodriquez A, Bordin G, Bebianno M, DeLey M, Sestakova I, Vasak M, Nordberg M: Recent developments in quantification methods for metallothionein. Journal of Inorganic Biochemistry 2002; (88), 123-134.

Cole R: Some tenets pertaining to electrospray ionization mass spectrometry. Journal of Mass Spectrometry 2000; (35), 763-772.

Gehrig P, You C, Dallinger R, Gruber C, Brouwer M, Kagi J, and Hunziker P: Electrospray ionization mass spectrometry of zinc, cadmium, and copper metallothioneins: evidence for metal-binding cooperativity. Protein Science 2000; (9), 395-402.

Hathout Y, Reynolds K, Szilagyi Z, Fenselau C: Metallothionein dimmers studied by nano-spray mass spectrometry. Journal of Inorganic Biochemistry 2002; (88), 119122.

He T, Wei D, Fabris D, and Fenselau C: Intracellular sequestration of anti-tumor drugs by metallothionein. Cellular and Molecular Biology 2000; (46), 383-392. 
Hong S, Toyama M, Maret W, and Murooka Y: High yield expression and single step purification of human thionein/metallothionein. Protein Expression and Purification 2001; (21), 243-250.

Hunziker P: Cysteine modification of metallothionein. Methods in Enzymology 1991; (205), 399-400.

Ishida T, Kumagai Y, Ikeda Y, Ito K, Yano M, Toki S, Mihashi K, Fujioka T, Iwase Y, and Hachiyama S: (8S)-(Glutathion-S-YL)dihydromorphinone, a novel metabolite of morphine from guinea pig bile. Drug Metabolism and Disposition 1989; (17), 7781.

Koh M, and Kim H: The effects of metallothionein on the activity of enzymes involved in removal of reactive oxygen species. Bulletin of the Korean Chemical Society $2001 ;(22), 362-366$.

Linhart I: Stereochemistry of styrene biotransformation. Drug Metabolism Reviews 2001; (33), 353-367.

Nordberg G, Nordberg M, Piscator M, Vesterberg O: Separation of two forms of rabbit metallothionein by isoelectric focusing. Biochemical Journal 1972; (126), 491498.

Prange A, Schaumloffel D: Hyphenated techniques for the characterization and quantification of metallothionein isoforms. Analytical and Bioanalytical Chemistry 2002; (373), 441-453. 
Price E, Smith J, Clark C, Schlager J and Shih M: MALDI-TOF/MS as a diagnostic tool for confirmation of sulfur mustard exposure. Journal of Applied Toxicology 2000; (20), S193-S197.

Research collaboratory for structural bioinformatics (RCSB), protein data bank:

Rutgers, State University of New Jersey. http://www.rscb.org/pdb/. 2003.

Rigby K, Stillman M: Structural studies of metal-free metallothionein. Biochemical and Biophysical Research Communications 2004; (325), 1271-1278.

Sanz-Nebot V, Andon B, Barbosa J: Characterization of metallothionein isoforms from rabbit liver by liquid chromatography coupled to electrospray mass spectrometry. Journal of Chromatography B 2003; (796), 379-393.

Sato M, Hida M, Nagase H. Analysis of pyrolysis products of dimethylamphetamine. Journal of Analytical Toxicology 2001; (25), 304-309.

Shaw C, He L, Munoz A, Savas M, Chi S, Fink C, Gan T, Petering D: Kinetics of reversible $\mathrm{N}$-ethylmaleimide alkylation of metallothionein and the subsequent metal release. Journal of Biological Inorganic Chemistry 1997; (2), 65-73.

Swiss-prot protein knowledgebase: ExPASy (expert protein analysis system) proteomics server of the Swiss institute of bioinformatics (SIB). http://au.expasy.org/sprot/sprot.top.html. 2003.

Szilagyi Z, Fenselau C: Molecular dynamics simulation of metallothionein-drug complexes. Drug metabolism and Disposition 2000; (28), 174-179. 
Watabe T, Hiratsuka A, Ozawa N, Isobe M: Glutathione S-conjugates of phenyloxirane. Biochemical Pharmacology 1981; (30), 390-392.

Wei D, Fabris D, and Fenselau C: Covalent sequestration of phosphoramide mustard by metallothionein- an in vitro study. Drug Metabolism and Disposition 1999; (27), 786-791.

Yu X, Zhuchun W, and Fenselau C: Covalent sequestration of melphalan by metallothionein and selective alkylation of cysteines. Biochemistry 1995; (34), 33773385.

Zaia J, Fabris D, Wei D, Karpel R, and Fenselau C: Monitoring metal ion flux in reactions of metallothionein and drug-modified metallothionein by electrospray mass spectrometry. Protein Science 1998; (7), 2398-2404.

Zaia J, Jiang L, Han M, Tabb J, Wu Z, Fabris D, and Fenselau C: A binding site for chlorambucil on metallothionein. Biochemistry 1996; (35), $2830-2835$.

Zangger K, Shen G, Oz G, Otvos J, Armitage I: Oxidative dimerization in metallothionein is a result of intermolecular disulphide bonds between cysteines in the $\alpha$-domain. Biochemical Journal 2001; (359), 353-360. 